OPEN ACCESS

Edited by:

Prashant Trikha,

Nationwide Children's Hospital,

United States

Reviewed by:

Nejat K. Egilmez,

University of Louisville, United States

Doug Palmer

National Cancer Institute (NCl),

United States

*Correspondence:

Connor J. Dwyer

dwyerc@musc.edu

Chrystal M. Paulos

paulos@musc.edu

Specialty section:

This article was submitted to

Cancer Immunity and Immunotherapy,

a section of the journal

Frontiers in Immunology

Received: 03 December 2018

Accepted: 30 January 2019

Published: 20 February 2019

Citation:

Dwyer CJ, Knochelmann HM

Smith AS, Wyatt MM, Rangel Rivera GO, Arhontoulis DC, Bartee $E$

Li Z, Rubinstein MP and Paulos CM (2019) Fueling Cancer Immunotherapy With Common Gamma Chain

Cytokines. Front. Immunol. 10:263. doi: 10.3389/fimmu.2019.00263

\section{Fueling Cancer Immunotherapy With Common Gamma Chain Cytokines}

\author{
Connor J. Dwyer ${ }^{1,2 *}$, Hannah M. Knochelmann ${ }^{1,2}$, Aubrey S. Smith ${ }^{1,2}$, Megan M. Wyatt ${ }^{1,2}$, \\ Guillermo O. Rangel Rivera ${ }^{1,2}$, Dimitrios C. Arhontoulis ${ }^{1,2}$, Eric Bartee ${ }^{1}$, Zihai Li ${ }^{1}$, \\ Mark P. Rubinstein ${ }^{1,3}$ and Chrystal M. Paulos ${ }^{1,2 *}$ \\ ${ }^{1}$ Department of Microbiology and Immunology, Medical University of South Carolina, Charleston, SC, United States, \\ ${ }^{2}$ Department of Dermatology and Dermatologic Surgery, Medical University of South Carolina, Charleston, SC, \\ United States, ${ }^{3}$ Department of Surgery, Medical University of South Carolina, Charleston, SC, United States
}

Adoptive T cell transfer therapy (ACT) using tumor infiltrating lymphocytes or lymphocytes redirected with antigen receptors (CAR or TCR) has revolutionized the field of cancer immunotherapy. Although CAR T cell therapy mediates robust responses in patients with hematological malignancies, this approach has been less effective for treating patients with solid tumors. Additionally, toxicities post T cell infusion highlight the need for safer ACT protocols. Current protocols traditionally expand T Iymphocytes isolated from patient tumors or from peripheral blood to large magnitudes in the presence of high dose IL-2 prior to infusion. Unfortunately, this expansion protocol differentiates $T$ cells to a full effector or terminal phenotype in vitro, consequently reducing their long-term survival and antitumor effectiveness in vivo. Post-infusion, T cells face further obstacles limiting their persistence and function within the suppressive tumor microenvironment. Therapeutic manipulation of $T$ cells with common $\gamma$ chain cytokines, which are critical growth factors for $T$ cells, may be the key to bypass such immunological hurdles. Herein, we discuss the primary functions of the common $\gamma$ chain cytokines impacting $T$ cell survival and memory and then elaborate on how these distinct cytokines have been used to augment T cell-based cancer immunotherapy.

Keywords: chimeric antigen receptor, T cell, adoptive cell transfer, gamma chain cytokines, TRUCKs

\section{INTRODUCTION}

The field of cancer immunotherapy, encompassing vaccines, checkpoint modulators, and adoptive T cell transfer therapy (ACT), has improved treatment outcomes in patients by harnessing the immune system to target their malignancy, sometimes resulting in cures (1). ACT uses either tumor-infiltrating lymphocytes (TILs) already equipped with tumor-specificity or peripheral blood lymphocytes genetically redirected with tumor-specific $\mathrm{T}$ cell receptors (TCRs) or chimeric antigen receptors (CARs) (2). Two different groups in the 1980's first revealed that T cells could be successfully redirected with an antigen receptor. Kuwana and team engineered a CAR that combined the immunoglobulin variable regions with a TCR constant region and they reported specificity against phosphorylcholine-specific bacteria (3). Gross et al. then used a similar construct but made the transformants specific for TNP-expressing cancer cell lines. They demonstrated that these CAR T cells could secrete IL-2 and lyse tumor cells in an antigen-specific manner (4). In some instances, engineering cells with a CAR instead of a TCR can be advantageous. This advantage stems from the fact that CARs, similar to antibodies, are able to recognize free unmodified antigen 
while TCRs require antigen modification and presentation by the major histocompatibility complex (MHC), which is often downregulated on tumor cells (5). However, unlike TCRs, CAR antigen specificity is restricted to cell surface antigens.

Following the two initial studies, CAR designs have been further modified to enhance their antitumor properties and persistence. First-generation CARs use a single chain variable fragment $(\mathrm{scFv})$ for antigen recognition and an intracellular signaling domain, $\mathrm{CD} 3 \zeta$ or FceRI $\gamma$ (6). In recent years, the incorporation of one or more co-stimulatory domains (i.e., second and third generation CARs) was instrumental to the success of CAR $\mathrm{T}$ cell efficacy for patients in clinical trials. As reviewed by Knochelmann et al., donor lymphocytes have been further modified in many ways by (1) incorporating targets to multiple antigens, (2) converting suppressive signals such as TGF- $\beta$ or IL- 4 into activating signals, (3) overexpression of chemokine receptors to enhance migration, and (4) secreting cytokines or soluble factors to modulate donor TIL or CAR $\mathrm{T}$ cells and endogenous immune cell function to induce a proinflammatory or "hot" tumor microenvironment $(7,8)$.

The most notable recent successes with CAR T cell therapy have resulted from the use of second generation CD19-CAR $\mathrm{T}$ cells for $\mathrm{B}$ cell derived malignancies that incorporate CD28 or 4-1BB costimulatory domains. Administration of CD19CAR T cells leads to near complete eradication of $\mathrm{CD} 19^{+}$ malignant and B cell lineage cells in patients with advanced lymphomas (9-14) and multiple forms of chemo-refractory or advanced leukemias (15-23). In many of these studies, CAR $\mathrm{T}$ cell therapy induced long term remissions in patients who had been heavily pre-treated with various ineffective therapies. Due to their unprecedented success in multiple patients in clinical trials, the second generation CD19-CAR containing 4$1 \mathrm{BB}-\mathrm{CD} 3 \zeta$ (Tisagenlecleucel) was FDA approved for patients with B cell acute lymphoblastic leukemia in 2017 and diffuse large B cell lymphoma in 2018 while the second generation CD19-CAR containing CD28-CD3 $\zeta$ (Axicabtagene ciloleucel) was approved for diffuse large B cell lymphoma in 2017 (7). Indeed, these therapies have revolutionized treatment for many patients around the world suffering from advanced hematological malignancies.

Though CAR T cell therapy has demonstrated incredible success with certain hematologic cancers, challenges still remain today in using this therapy to successfully treat patients with solid tumors. There also remains challenges in managing treatment-associated toxicity. Toxicities associated with CAR T cell therapy can be numerous including (1) cytokine release syndrome (CRS) which is characterized by a fever induced by high serum levels of IL-6 and IFN $\gamma$ (2) respiratory distress and (3) neurological symptoms (23-26). All of these toxic side effects can be lethal in individuals if left untreated (23-26). To manage these adverse events, patients are treated with drugs to block CRS such as IL-6 inhibition with tocilizumab (antiIL-6R) or corticosteroids $(23,24)$. For the treatment of solid tumors, CAR T cell therapies have poor efficacy due to tumor mediated suppression by (1) inhibitory receptor engagement, (2) soluble factors, (3) recruitment of suppressive immune cells, (4) nutrient deprivation and (5) loss of tumor antigen (5, 27-30).
As solid tumor-specific antigens are difficult to identify, patients can experience toxic side effects due to on-target off-tumor reactivity leading to autoimmune-like symptoms (26, 31-37). Consequently, investigators have more recently designed CAR T cell constructs containing an inducible suicide gene to rapidly eliminate CAR T cells from the patient with a pharmacological reagent. The hope is that this approach will theoretically reverse or reduce the onset of these adverse events (38-42).

Novel ways to improve the potency of CAR T cells in the tumor are desperately needed for patients that fail conventional chemotherapies or other forms of cancer immunotherapy. T cell function, survival, and proliferation are strongly influenced by cytokine signaling. Notably, the members of the common $\gamma$ chain $(\gamma \mathrm{c})$ cytokine family play pivotal roles in fueling T cells to thrive, lyse tumors and drive long-lived memory to tumor relapse or metastasis. While IL-2 has been widely used to expand T cells ex vivo in preparation for infusion into patients, preclinical work reveals that other members of the $\gamma c$ cytokine family should be considered for clinical use. Consequently, this review will detail the basic biology of various $\gamma c$ cytokines, including IL-2, IL4, IL-7, IL-9, IL-15, and IL-21 and discuss how each cytokine has have been used in cellular therapy. Lastly, we will discuss a subset of fourth generation CARs known as TRUCKs ( $\mathrm{T}$ cell redirected for universal cytokine-mediated killing) in cancer immunotherapy and discuss our vantage of how to best augment their antitumor potency using $\gamma c$ cytokines in vitro and in vivo to safely improve treatment outcomes in patients with advanced blood or solid tumors.

\section{OVERVIEW: COMMON $\gamma$ CHAIN CYTOKINE SIGNALING AND FUNCTION IN T LYMPHOCYTE BIOLOGY}

Common $\gamma$ chain cytokines exert numerous functions on $\mathrm{T}$ lymphocyte survival, function and proliferation. As illustrated in Figure 1, the $\gamma$ c family consists of six members-IL-2, IL-4, IL-7, IL-9, IL-15, and IL-21-which all have unique receptors. Upon receptor ligation, $\gamma c$ cytokines through JAK1 and JAK3 activate various developmental pathways including STAT1, STAT3, STAT5, MAPK, and PI3K/AKT pathways (4355). The one exception is IL-4, which in addition to STAT5, MAPK and PI3K/AKT pathways, activates STAT6 signaling (5662). Below, we will further discuss receptor composition and the biological functions exerted by each of these six $\gamma$ c cytokines.

\section{IL-2}

IL-2 is primarily produced by activated T cells upon TCR and costimulatory signaling (43). As displayed in Figure 1, the IL-2 receptor (IL-2R) is a trimeric receptor that consists of IL-2R $\alpha$, IL-2R $\beta$ and the $\gamma c$ where signaling is ultimately mediated through IL-2R $\beta$ and the $\gamma c(43,44)$. High affinity IL$2 \mathrm{Rs}(\alpha \beta \gamma)$ are expressed on activated T cells and constitutively expressed on $\mathrm{T}$ regulatory cells (Tregs) while the intermediate affinity IL-2R $(\beta \gamma)$ is expressed on natural killer (NK) cells and memory $\mathrm{CD}^{+}{ }^{+} \mathrm{T}$ cells (43). IL-2 has non-redundant functions in both Treg and effector T cell biology. For Tregs, IL-2 is 


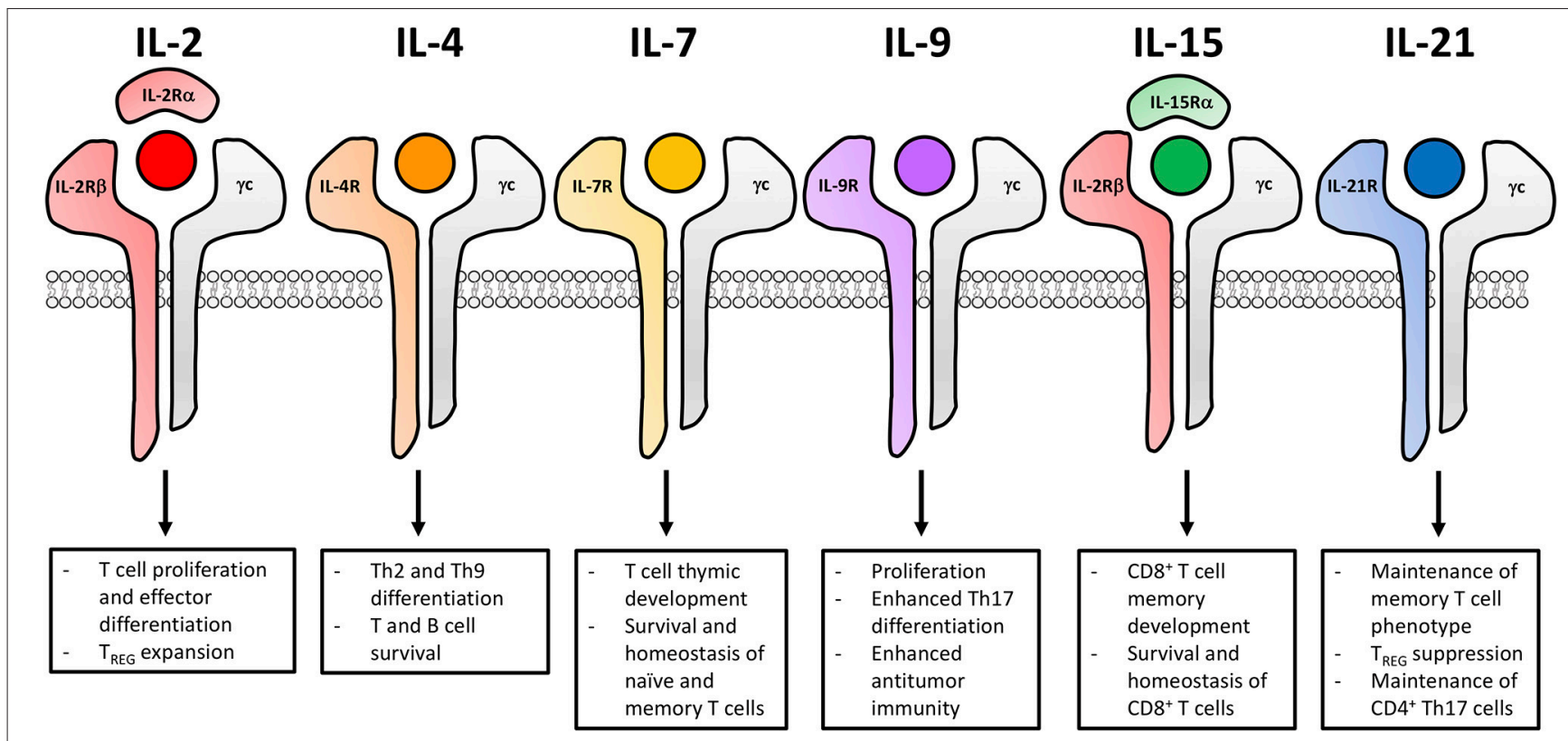

FIGURE 1 | Common $\gamma$ chain cytokine signaling impacts the functional fate of T cells for adoptive cell transfer. The six members of the $\gamma \mathrm{c}$ cytokine family (IL-2, IL-4, IL-7, IL-9, IL-15, and IL-21) and the composition of their unique cytokine receptors. Signaling cascades from these receptors lead to distinct biological outcomes impacting differentiation, effector function and memory development of $\mathrm{T}$ cells.

essential for thymic development, peripheral homeostasis, and suppressive function (63-74). In IL-2-, IL-2R $\alpha-$, and IL-2R $\beta$ deficient models, mice succumb to lethal autoimmunity within 8-12 weeks due to impaired thymic development of Tregs (6366). Conversely, effector $\mathrm{T}$ cells readily develop in IL-2-, IL$2 \mathrm{R} \alpha-$, and IL-2R $\beta$-deficient models. However, IL-2 is essential for the optimal proliferation and differentiation of effector $\mathrm{T}$ cells and this cytokine influences their contraction through activation induced cell death (AICD) (75). Additionally, IL-2 plays distinct roles in the function of various $\mathrm{CD} 4^{+} \mathrm{T}$ helper (Th) subsets. The differentiation of Th1, Th2, Th9, and iTreg subsets is promoted by increased expression of IL-2 while Th17 and Tfh differentiation is suppressed by IL-2 (76-81). IL-2R signaling intensity influences the development, survival and recall response of $\mathrm{T}$ cell memory (82-85). Low IL-2R signaling favors the development of central memory T cells (Tcm) whereas high IL-2R signaling favors the development of effector memory $\mathrm{T}$ cells (Tem) and terminally-differentiated effector cells (86). IL-2 also influences effector development through the upregulation of IFN $\gamma$, perforin, granzyme B and Blimp-1, which drive terminal effector differentiation and suppresses expression of makers associated with memory (such as Bcl-6, CD127, and CD62L) (86-89).

\section{IL-4}

The cytokine IL-4 has long been appreciated to impact humoral immunity. IL-4 is primarily produced by $\mathrm{CD}^{+} \mathrm{T}$ cells (specifically Th2 and Tfh cells), basophils, eosinophils, mast cells and NKT cells (90-98). Along with the $\gamma$ c receptor, IL-4 binds to IL-4R $\alpha$ (Figure 1). Upon IL-4 receptor (IL-4R) signaling, cascades promote the up-regulation of IL- $4 \mathrm{R} \alpha$, which induces a positive feedback loop $(62,99,100)$. IL-4 is required for the differentiation of naïve $\mathrm{CD} 4^{+} \mathrm{T}$ cells to a Th2 phenotype. This cytokine also induces and immunoglobulin class switching in $\mathrm{B}$ cells, promotes the survival of $\mathrm{T}$ and $\mathrm{B}$ cells and drives long-term development of CD8 ${ }^{+} \mathrm{T}$ cell memory (101). Humoral immunity is dependent on IL-4, as IL-4-, or IL-4R-deficient mouse models have impaired antibody production, high susceptibility to parasitic infection and diminished Th2 differentiation (101). IL-4 is thought to be controversial for cancer therapy because multiple forms of cancer express the IL-4R. Increased IL-4R expression has been observed in renal cell carcinoma, melanoma, breast, glioblastoma, lung, prostate, bladder and head neck cancers (102-107). Angiogenesis of human breast tumor cells has been shown to be inhibited by the addition of IL-4, preventing metastatic growth and proliferation $(108,109)$. However, since both adipose tissue and cancer cells secrete IL-4 to promote a suppressive tumor microenvironment, blocking IL-4R signaling was found to decrease the viability of breast tumor cells (110). Finally, recent data has emerged that, along with TGF- $\beta$, IL-4 can support the generation of a new subset called Th9 cells. These cells secrete IL-9 and have been reported to augment immunity to tumors in ACT models $(111,112)$. Indeed, future investigations are required to better understand the role of IL- 4 in regulating Th2 and Th9 cells in adoptive immunotherapy for cancer.

\section{IL-7}

In contrast to IL-2, cytokine IL-7 is not produced by hematopoietic cells but rather is secreted by stromal cells (113-115). Its receptor consists of the $\gamma c$ and a unique IL-7R $\alpha$ (Figure 1) (113). The fundamental role of IL-7 has been demonstrated in both humans and in mice with 
deficiency in either IL-7 or the IL-7 receptor (IL-7R) resulting in impaired thymic development of mature lymphocytes resembling severe combined immune deficiency (116-118). Moreover, IL-7 supports the survival and homeostasis of naïve and memory $\mathrm{T}$ cells (119-124). Upon activation and IL$7 \mathrm{R}$ signaling, the IL-7R is down-regulated on naïve $T$ cells. Interestingly, IL-7R is re-expressed on Tcm and Tem cells (125128). It is important that cells express IL-7R as IL-7 signaling promotes the homeostasis and survival of naïve and memory $\mathrm{T}$ cells via the up-regulation of $\mathrm{Bcl}-2$ and the suppression of proapoptotic mediators $(49,129-131)$. Unlike IL-2, IL-7 does not induce Treg proliferation, as IL-7R $\alpha$ is expressed at low levels on this suppressive lymphocyte population $(132,133)$. Due to the deleterious role of Tregs in cancer immunotherapy, many investigators are now exploring the role of IL-7 in potentiating checkpoint modulators or $\mathrm{T}$ cell therapies, as discussed in greater detail later in this review.

\section{IL-9}

IL-9 was initially described as a T cell growth factor. However, IL-9 is more recently appreciated for its role in the proliferation and differentiation of mast cells as well as its involvement in B cell maturation (134-137). IL-9 is primarily produced by various $\mathrm{CD}^{+} \mathrm{T}$ cell subsets (naïve, Th2, Th9, Th17, and Tregs) but can also be made by mast cells, NKT cells and type 2 innate lymphoid cells (ILC2) $(112,138-145)$. As shown in Figure 1, IL-9 signals through the $\gamma \mathrm{c}$ and IL-9R $\alpha$ which is expressed on activated T cells, mast cells and macrophages $(52,146)$. In IL-9- and IL9 receptor (IL-9R)-deficient mice, there was no effect on T cell differentiation or development, but these mice had diminished mast cell proliferation (147). Additional investigations revealed that experimental autoimmune encephalomyelitis was markedly reduced in IL-9R-deficient mice compared to wild-type cohorts, as $\mathrm{CD} 4^{+} \mathrm{T}$ cells and macrophages from these mice secreted less IL-17 and IL-6, respectively (148). Importantly, IL-9 also plays roles in regulating transplant tolerance, promoting anti-parasitic immunity, exacerbating allergy and autoimmunity (149). The role of IL-9 in tumor immunity has been controversial, both promoting antitumor immunity and enhancing transformation and tumor growth. It has been reported that IL-9 overexpression promotes cell proliferation, metastasis and survival of pancreatic cancer and lymphomas (150-152). However, the adoptive transfer of antitumor Th9 or Tc9 cells regress melanoma in mice through IL-9-dependent mechanisms and are highly cytolytic, hyperproliferative, and persistent post transfer into animals (153-157).

\section{IL-15}

As depicted in Figure 1, IL-2 and IL-15 share common receptor subunits, IL-2R $\beta$ and the $\gamma c$, only differing between the unique $\alpha$ subunits (53). IL- $15 R \alpha$ is expressed on activated monocytes and dendritic cells and because of IL-15R $\alpha$ 's high affinity for IL15 , IL-15 can be trans-presented to IL-2R $\beta$ and the $\gamma c$ on NK and $\mathrm{CD} 8^{+} \mathrm{T}$ cells, unlike IL-2 which is primarily cis-presented $(53,158)$. Also, in contrast to IL-2, IL-15 is primarily produced by innate immune cells (including dendritic cells, macrophages and monocytes) (159-162). IL-15 and IL-15R signaling are important for the development and homeostasis of $\mathrm{NK}$ cells and $\mathrm{CD}^{+}{ }^{+} \mathrm{T}$ cells though the up-regulation of anti-apoptotic markers Mcl1 and Bcl-2 while inhibiting AICD (163-174). This discovery became clear in studies using IL-15- and IL-15R-deficient mouse models, which have impaired $\mathrm{NK}$ cell and $\mathrm{CD} 8^{+} \mathrm{T}$ memory cell development and compromised lymph node homeostasis $(164,175)$. IL-15, unlike IL-2, preferentially expands CD8 ${ }^{+} \mathrm{T}$ cell memory and NK cells in the presence of Treg cells while promoting resistance to Treg suppression $(176,177)$.

\section{IL-21}

IL-21 has been reported to improve antitumor T cell immunity but has also been identified as a potent mediator of autoimmunity (178). IL-21 is primarily produced by activated $\mathrm{CD} 4^{+} \mathrm{T}$ cells, particularly Th17 and Tfh but can also be produced by NKT cells (179-181). As shown in Figure 1, the IL-21 receptor (IL-21R) is comprised of the $\gamma \mathrm{c}$ and IL-21R $\alpha(182,183)$. Receptor expression is low on resting $\mathrm{T}$ cells but is upregulated upon TCR activation or IL-21 stimulation (183-185). Both adaptive and innate immune cells are influenced by IL-21 as T, B, NKs, macrophages and DCs all express the IL-21R $(179,181,183,184,186)$. IL-21 promotes the proliferation, survival and differentiation of Th17 and Tfh subsets while enhancing the function of cytotoxic $\mathrm{CD} 8^{+}$ T cells (187-197). Additionally, IL-21 blunts Treg expansion by suppressing Foxp3 expression and favors the enrichment of antigen-stimulated $\mathrm{CD} 8^{+} \mathrm{T}$ cells (198). Th17 and Th2 immune responses are impaired while Tregs are increased in IL-21- and IL-21R-deficient mice $(190,191,199,200)$.

Collectively, $\gamma c$ cytokines play a major role influencing the development, differentiation, and survival of innate and adaptive immune cells. For cancer treatment, $\gamma c$ cytokines have been used systemically as monotherapies to harness endogenous immune responses, or in combination with ACT to improve antitumor efficacy. The presence of $\gamma c$ cytokines at various points in the $\mathrm{T}$ cell development including priming, ex vivo expansion, or post adoptive transfer can influence the function of tumorspecific T cells. As both IL-4 and IL-9 have not been thoroughly explored for ACT and have controversial roles in both promoting tumorigenesis and mediating antitumor immunity, we will focus the rest of our discussion on the clinical uses of IL-2, IL-7, IL15 , and IL-21 for immunotherapy, and their potential to improve patient responses to T-cell based therapies.

\section{CLINICAL USES OF IL-2, IL-7, IL-15, AND IL-21 IN CANCER IMMUNOTHERAPY Interleukin-2: T Cell Proliferation at the Cost of Treg Expansion}

Currently, IL-2 is the only $\gamma$ c cytokine to be FDA-approved to treat patients with cancer. In anti-cancer therapies, this cytokine is commonly administered to patients to augment the engraftment and function of adoptively transferred $\mathrm{T}$ cells. For treatment of several autoimmune disorders such as type 1 diabetes, $\mathrm{HCV}$-induced vasculitis and graft vs. host disease (GVHD), IL-2 is administered at low doses and has been beneficial for patients because it targets the constitutive 
expression of the high affinity IL-2R leading to selective proliferation of Tregs (201-204). Conversely, effector T cells do not readily express the high affinity IL-2R. High dose IL-2 is administered to cancer patients to support the proliferation and function of cytotoxic T lymphocytes (CTLs) $(205,206)$. In fact, since the 1980s high dose IL-2 has been used to treat patients with renal cell carcinoma and metastatic melanoma (207-210). Standard treatment protocols involve the administration of 720,000 IU IL-2/kg every $8 \mathrm{~h}$ for up to 14 consecutive doses. Using high-dose IL-2 for patients with renal cell carcinoma, $14 \%$ of patients (255 patients total) had an objective response, while 12 patients experienced a complete response (209). Similar efficacy was observed with high-dose IL-2 treatment for metastatic melanoma, where $16 \%$ of patients (270 patients total) had an objective response with 17 patients having a complete response and 26 patients experiencing a partial response (210). High dose IL-2 treatment was FDA-approved for renal cell carcinoma in 1992 and for metastatic melanoma in 1998 (211, 212). However, due to toxicities associated with this therapy such as hypotension, capillary leak syndrome, cardiac toxicity, and renal failure, many cancer centers stopped using this therapy to treat patients (213215). Today, IL-2 is mainly used to expand TILs or CARs ex vivo for ACT and is administered to the patient to support donor cell expansion post-transfer.

As IL-2 promotes the differentiation of naive $\mathrm{CD} 8^{+} \mathrm{T}$ cells to full effectors and generates Tregs in the ACT products (Figure 2), immunologists have focused on preferentially targeting IL-2 to effector T cells. One promising way to target IL-2 to effectors has been by complexing this cytokine with anti-IL-2 antibodies. This IL-2 complex uniquely presents IL-2 to the intermediate but not high affinity IL-2Rs thereby reducing Treg expansion (216-219). The importance of targeting IL-2 to transferred T cells has also shown promise in the field of cancer immunotherapy. For example, Rubinstein and colleagues discovered that IL$2 \mathrm{R} \alpha$ on transferred $\mathrm{T}$ cells sustained signaling by promoting recycling of endocytosed IL-2 back to the cell surface (220). This recycling mechanism raised the possibility of engineering TILs or CARs to express IL-2R $\alpha$ to improve IL-2-based therapies (220). Furthermore, other groups have recently discovered novel ways to specifically target transferred $T$ cells with IL-2. In fact, Sockolosky et al. engineered a synthetic IL-2 and IL-2R (distinct from native IL-2 and the IL-2R) and expressed them on transferred $\mathrm{T}$ cells. The synthetic IL-2R did not interact with native IL-2, could mediate IL-2R signaling, thereby leading to the selective proliferation of CTLs and regression of melanoma in mice (221).

TIL therapies require expansion of ample numbers of lymphocytes from the suppressive tumor microenvironment. Ex vivo, patient tumor samples are treated with high dose IL2 to preferentially expand TIL. These TIL are then rapidly expanded in the presence of anti-CD3, IL-2 (6000IU/mL) and irradiated feeder cells for several weeks in order to propagate them to the billions (222). After expansion, TIL are infused into the patient who has been preconditioned with a nonmyeloablative preparative regimen $(2,212,223)$. Upon transfer, IL-2 is administered to patients to promote the expansion of donor TILs in vivo because these cells have increased IL-2R $\alpha$ as expression is positively regulated by TCR and IL-2R signaling (43). In a preclinical model using Epstein Barr Virus positive tumors, EBV-specific CTLs were engineered to express IL-2 or IL-15. Transgenic expression of IL-2 or IL-15 increased T cell expansion in vitro and in vivo ultimately enhancing their in vivo efficacy (224). Treating melanoma patients with ex vivo expanded TIL and high dose IL-2 (720,000 IU/kg) led to complete remission in 20 of 93 patients and some patients experienced long-term remission (225). Transducing melanoma TIL to continually secrete IL-2 bypassed the need for exogenous administration of IL-2 to the patient. These modified cells survived in the patient but surprisingly did not improve clinical outcomes compared to TIL administered with exogenous IL-2 $(226,227)$.

Similar to TIL therapies, IL-2 promotes the proliferation of CAR T cells. Yet this cytokine also drives their differentiation into terminal effector phenotypes. In pancreatic ductal adenocarcinoma xenograft models, treatment of mesothelinspecific CAR T cells with a TNF $\alpha$ and IL-2-secreating adenovirus increased their activation, proliferation and antitumor response in mice (228). IL-2 also increases resistance of CD28-CD3ל CARs in vitro to TGF $\beta$-mediated suppression compared to 4-1BB-CD3 $\zeta$ CARs. CD28 costimulation activates Lck, which promotes IL-2 production and if Lck is nonfunctional, CAR T cells have impaired antitumor activity (229). It has also been reported that CAR T cells expanded with IL-2 (100 IU/mL) for 3 days, compared to 10 days, generated lymphocytes with an increased proportion of "younger" memory-like cells $(230,231)$. With longer culture time and increased differentiation, CARs mediated slightly reduced anti-leukemia immunity in mice (230). Ablation of IL-2R $\alpha$ on CAR T cells did not improve their function but did decrease their expansion capabilities in vitro (230). While IL-2 promotes the differentiation of naïve $\mathrm{T}$ cells to an effector phenotype, IL-2R $\beta$ signaling has been clearly shown to improve the function of CAR $\mathrm{T}$ cells. In a recent study conducted by Kagoya et al. CAR T cells were engineered to express a truncated IL-2R $\beta$ domain (232). This truncated domain increased STAT3 and STAT5 signaling and improved their expansion in vivo. When these cells were transferred into mice bearing leukemia or melanoma, they had improved survival and regressed hematological and solid tumors more effectively compared to their traditional CAR cohorts (232). To circumvent the negative attributes of IL-2, investigators have also been turning their focus to other $\gamma$ c cytokines including IL-7, IL-15, or IL-21 which may prove to be better candidates to improve methodology for ACT therapy.

\section{Interleukin-7: Naïve and Memory Cell Proliferation Without Treg Expansion}

Similar to IL-2, IL-7 promotes the proliferation of naïve and memory T cells. Thus, IL-7 is a promising cytokine for cancer immunotherapy. The benefit of IL-7 for ACT was first shown in preclinical models treating CTL's in vitro with either IL-7 or IL-2. When transferred into mice, IL-7-treated CTLs controlled metastatic disease to the same extent as those treated with IL-2 (233). In clinical trials using recombinant human IL-7 (rhIL7) as a monotherapy, IL-7 was shown to be well tolerated 


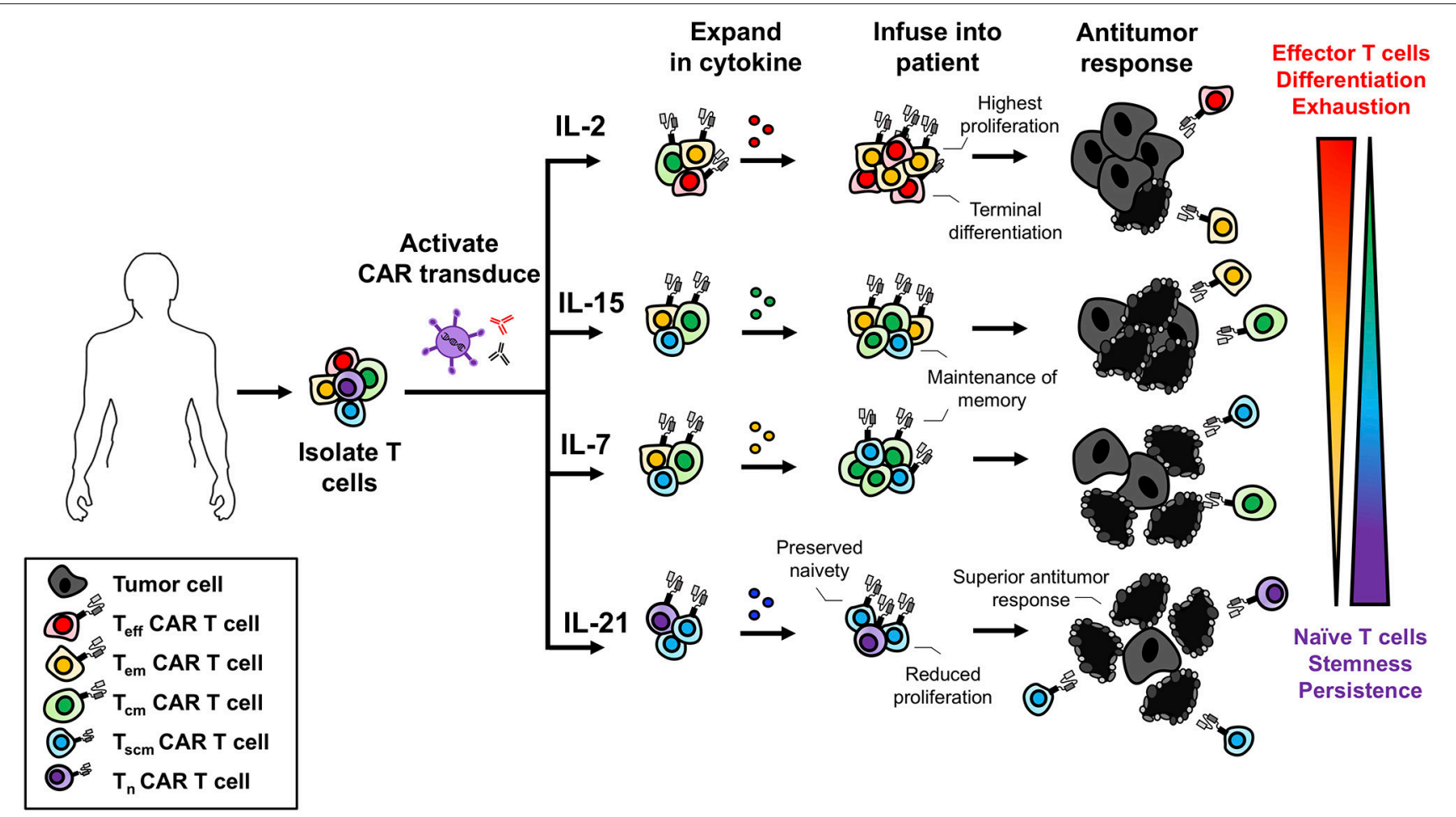

FIGURE 2 | Use of $\gamma c$ cytokines for ex vivo T cell expansion generates T cells with variable memory phenotypes. $\gamma \mathrm{c}$ cytokines promote different biological programs that influence the differentiation of T cells. While IL-2 promotes robust proliferation it also promotes terminal effector differentiation. IL-7 and IL-15 maintain the homeostasis and survival of memory T cells and treatment ex vivo promotes a Tscm/Tcm phenotype. IL-21 slows T cell expansion but prevents differentiation and maintains a naïve-like $T$ cell phenotype. With respect to antitumor immunity, less differentiated cell products are more therapeutic leading to the understanding that IL-2 is not the best option for ex vivo expansion.

by patients with advanced malignancies $(234,235)$. Rosenberg and colleagues treated a cohort of 12 patients (11 metastatic melanoma and 1 metastatic sarcoma) with 8 doses of IL-7 and found dose-dependent increases in $\mathrm{CD}^{+}$and $\mathrm{CD} 8^{+} \mathrm{T}$ cells with a decrease in Tregs (234). Following this work, Sportes and colleagues conducted an IL-7 dose-escalation study on 16 patients with non-hematologic non-lymphoid cancers and found similar results with increased $\mathrm{CD}^{+}{ }^{+} \mathrm{T}$ cells and decreased Tregs (235). TCR-repertoire analysis of T cells indicated a more diverse repertoire, signifying IL-7's role in promoting a broader immune response and the selective expansion of naïve $\mathrm{T}$ cells (235). Culturing naïve $\mathrm{T}$ cells from healthy donors with IL-7, expands $\mathrm{T}$ stem cell memory $(\mathrm{Ts} \mathrm{cm}$ ) cells to a greater extent than IL-2 treatment (236). These Tscm were defined as $\mathrm{CD}_{2} \mathrm{~L}^{+} \mathrm{CCR}^{+}$ $\mathrm{CD}_{4} \mathrm{RA}^{+}{ }^{+} \mathrm{CD} 45 \mathrm{RO}^{+} \mathrm{IL}_{-7 \mathrm{R}}{ }^{+} \mathrm{CD}^{+} 5^{+}$and were shown to have increased expansion as well as a high capacity for self-renewal (236). IL-7 preferentially expanded naïve $\mathrm{T}$ cells to a Tscm phenotype compared to Tcm and Tem, likely because naïve cells express more IL-7R, as portrayed in Figure 2. As Tscm have been reported by several groups to mediate potent memory responses to tumors, it has become increasingly clear that IL-7 has promise in the clinical setting (237-240).

IL-7 has been used in CAR $\mathrm{T}$ cell therapy, often in combination with other cytokines, during the in vitro expansion phase. For example, CAR T cells expanded in the presence of IL-7, IL-4 and IL-21 were found to express less inhibitory receptors compared to IL-2-expanded cells. These cells also had an increased Tscm/Tcm phenotype and co-expressed CD27 and CD28 (241). In the presence of IL-7 and IL-15, CAR T cells possess a naïve/Tscm phenotype with improved proliferation upon antigenic-rechallenge compared to IL-2-treated CARs (242, 243). IL-7/IL-15 expanded CAR T cells have increased in vivo persistence, leading to improved antitumor immunity (244). MUC-1-specific CAR T cells have been engineered with a switch receptor containing an IL-4 ectodomain and an IL-7 endodomain to counter the IL-4-rich tumor microenvironment (245). By converting an IL-4 signal into an IL-7 signal, these $\mathrm{T}$ cells expanded robustly and mediated potent antitumor immunity in mice bearing breast tumors (245). Anti-CD20 CAR T cells engineered to express CCL19 and IL-7 migrate and expand to a greater extent than conventional CARs and led to complete remission of mastocytoma and Lewis lung carcinoma in mice (246). Additionally, IL-7 was critical to this response, as anti-IL$7 \mathrm{R} \alpha$ administration diminished the therapeutic benefit of these cells (246). Shum and colleagues engineered a GD-2-specific CAR T cell with constitutive IL-7R signaling, CD34 ectodomain and an IL-7R $\alpha$ endodomain, leading to constitutive STAT5 activation (247). These CARs were able to undergo multiple rounds of expansion and mediate a robust response against glioblastoma and metastatic neuroblastoma tumors (247). These 
CAR constructs highlight the beneficial role of IL-7 and IL$7 \mathrm{R}$ signaling in improving the antitumor functions of $\mathrm{T}$ cells for ACT.

\section{Interleukin-15: CD8 ${ }^{+}$Memory T Cell Expansion With Some NK Cell Assistance}

IL-15R signaling is promising for $\mathrm{T}$ cell-based cancer immunotherapies. This pathway selectively induces the expansion and function of $\mathrm{CD}^{+}$memory and NK cells (163168). For ACT, IL-15 has been used to enhance the activity of TIL and CAR T cells ex vivo. Moreover, IL-15 has also been complexed with IL-15R $\alpha$ and this novel agent has been used as an immunotherapy in cancer patients in vivo (248). When cultured in vitro, $\mathrm{T}$ cells expanded with IL-15, rather than IL-2, are predominately a Tcm phenotype with very few Tem $(249,250)$. Conversely, IL-2-expanded cells are mostly effectors (Figure 2) (249). In turn, IL-15 generates a cellular product that mediates improved antitumor immunity, as IL-15propogated $\mathrm{Tcm}$ have an improved engraftment potential and migratory capacity compared to IL-2-expanded cells $(250,251)$. Administration of recombinant IL-15 can promote immunity through the expansion of endogenous $\mathrm{CD}^{+} \mathrm{T}$ cells and $\mathrm{NK}$ cells $(252,253)$. In combination with checkpoint inhibition, IL-15 improved $\mathrm{CD}^{+} \mathrm{T}$ cell function marked by increased IFN $\gamma$ production and mice treated with the combination had improved control of metastatic disease (253). Additionally, IL-15 is able to reverse tumor-tolerant $\mathrm{CD}^{+}{ }^{+} \mathrm{T}$ cells, when IL-2 and IL-7 were unable to, restoring antigen responsiveness and leading to tumor clearance (254-256). In the first clinical trial using recombinant human IL-15 (rhIL-15) to treat 18 patients with metastatic cancer (11 metastatic melanoma and 7 renal cell carcinoma), rhIL-15 was administered intravenously in a dose escalating study for 12 consecutive days (257). From the 18 patients treated, there was only stable or progressive disease. The dosing regimen led to elevated serum levels of IL- 6 and IFN $\gamma$ along with grade 3 toxicities such as hypotension, lymphopenia and elevated aspartate and alanine aminotransferases at higher doses. However, minutes after administration of rhIL-15, NK, $\gamma \delta$, and $\mathrm{CD}^{+} \mathrm{T}$ cells effluxed from the blood and proliferated robustly for many days after administration (257). This study implicates the promising role of IL-15 to selectively target the homeostasis and expansion of $\mathrm{NK}$ and $\mathrm{CD} 8^{+} \mathrm{T}$ cells.

Complexing IL-15 with IL-15R $\alpha$ drastically increases the halflife of this cytokine, maximizing its activity while preferentially presenting IL-15 to cells expressing IL-2R $\beta$ and $\gamma \mathrm{c}(258,259)$. For example, ALT-803, an IL-15/IL-15R $\alpha$ sushi domain complex, mediated improved therapeutic benefit over native IL-15 (260, 261). Administration of ALT-803 in mice led to selective expansion of $\mathrm{NK}$ and $\mathrm{CD}^{+} \mathrm{T}$ cells with no expansion of Tregs, increased production of IFN $\gamma, \mathrm{TNF} \alpha$, and IL-10, and reduced metastasis of breast carcinoma, colon carcinomas, and myeloma in mice $(260,261)$. Therapeutic benefit was mediated by $\mathrm{CD}^{+} \mathrm{T}$ cells as their depletion diminished antitumor immunity (260-262). In a phase 1b clinical trial conducted by Wrangle et al. ALT-803 was administered with nivolumab (anti-PD-1) to 21 patients with metastatic non-small cell lung carcinoma
(263). ALT-803 could be safely administered to these patients in combination nivolumab. In fact, there were no dose limiting toxicities experienced by patients on this trial (263). Moreover, this therapy dramatically increased the proliferation of $\mathrm{NK}$ and $\mathrm{CD}^{+} \mathrm{T}$ cells in the blood (263). Although this study was not designed to assess efficacy, the authors reported evidence of the re-induction of antitumor responses in patients who failed to respond to nivolumab therapy alone (263). This study emphasizes the promise of using IL-15/IL-15R $\alpha$ complex in cancer therapy and also implies that ALT-803 may improve the antitumor activity of TIL or CAR therapies in patients without increased toxic side effects.

In a clinical trial treating 22 patients with advanced stage lymphoma, patients with positive tumor responses and complete remissions had increased IL-15 serum levels (12). Investigators have engineered IL-15-producing CARs to enhance $\mathrm{T}$ cell memory development and incorporate NK cell responses for tumor clearance in vivo. Anti-leukemia CAR $\mathrm{T}$ cells that express IL-15 have increased expansion, viability, and improved antitumor immunity compared to conventional CAR T cells in lymphoma xenograph models (264). In glioma xenograph models, IL-13R $\alpha 2$-specific CAR $T$ cells that secrete IL-15 showed increased proliferation, sustained cytokine production and improved survival (265). In this model, tumor relapse was observed due to the expansion of tumor cells that had lost expression of the target antigen. However, in some instances retroviral transduction of IL-15 can transform human primary $\mathrm{T}$ cells leading to prolonged cell survival, increased telomerase activity and resistance to apoptosis (266). Membrane-bound IL15 on CAR $\mathrm{T}$ cells mediated similar results, as demonstrated by their increased persistence and immunity against leukemia (238). Thus, IL-15 bolsters NK and $\mathrm{CD}^{+} \mathrm{T}$ cell expansion and function, which leads to improved immunity, implicating IL-15 as a beneficial cytokine for ACT (237). In the future, it will be paramount to understand the best way to deliver IL-15 therapy in combination with ACT and CAR T cell therapy.

\section{Interleukin-21: Preventing T Cell Differentiation to Increase Antitumor Immunity}

In a phase 1 clinical trial using recombinant human IL-21 (rhIL21 ) in a dose-escalation study with 43 patients (24 melanoma and 19 renal cell carcinoma patients), rhIL-21 was administered consecutively for 5 days for two full cycles. rhIL-21 was safe for patients and mediated antitumor immunity in some individuals, as demonstrated by 1 complete response and 4 partial responses (267). To follow this trial, Davis et al. conducted a phase IIa clinical trial treating 24 patients with metastatic melanoma with $30 \mu \mathrm{g} / \mathrm{kg}$ doses of IL-21 (268). Treatment with IL-21 led to 1 complete response and 1 partial response in this study. Additionally, IL-21 lead to the selective activation of NK and $\mathrm{CD}^{+} \mathrm{T}$ cells marked by increased expression of CD25, IFN $\gamma$, perforin and granzyme B (268). In a phase II trial with 40 metastatic melanoma patients, most of which had metastasis to the lungs, liver or lymph nodes, were treated with either $30 \mu \mathrm{g} / \mathrm{kg}$ or $50 \mu \mathrm{g} / \mathrm{kg}$ of IL-21 (269). Nine patients experienced partial 
responses where 16 patients had stable disease. There were 6 patients who experienced some dose-limiting toxicities amongst the treatment groups (267). Collectively, these trials indicate the benefit of IL-21 as a monotherapy and warrant the investigation combining IL-21 with other agents for cancer therapy.

IL-21 augments ACT therapy by preserving T cells in a less differentiated state ex vivo (88, 237, 250, 270, 271) (see Figure 2). While IL-2 drives robust proliferation and differentiation of $\mathrm{CD}^{+} \mathrm{T}$ cells, IL-21 enriches $\mathrm{CD}^{+} \mathrm{T}$ cells with a "younger" phenotype that express less IL-2R $\alpha, \mathrm{CD} 44$, and Eomes but have reduced expansion compared to those expanded with IL2 (88). However, when IL-21-stimulated $\mathrm{CD}^{+} \mathrm{T}$ cells were transferred into mice, they mediated superior anti-melanoma immunity compared to T cells treated in vitro with IL-2 or IL-15 (88). Additional investigation revealed that IL-21 supported the propagation of lymphocytes that expressed CD62L and secreted IL-2, consistent with Tscm phenotype. Moreover, these cells expressed Tcf1 and Lef7, which are transcription factors critical for the self-renewal of stem cells $(88,272,273)$. The benefits of IL-21 have been demonstrated on TILs isolated from ovarian or non-small cell lung carcinoma patients. While IL-2 greatly bolsters TIL expansion, IL-21 is unable to expand TIL alone (274). Importantly, IL-21 does not support the expansion of Treg cells in contrast to IL-2 (274). For human CD8 ${ }^{+}$T cells isolated from the peripheral blood of healthy donors, IL-21 promotes Tscm development in vitro leading to improved immunity upon adoptive transfer into mice with melanoma compared to IL-2stimulated $\mathrm{CD}^{+} \mathrm{T}$ cells (275). In addition to using IL-21 for treatment of $\mathrm{CD}^{+}$T cells ex vivo, IL-21 is a potent agent for the expansion of NK cells. Using membrane-bound IL-21 on artificial antigen-presenting cells, NK cells can be expanded to large numbers to elicit graft vs. leukemia responses without inducing GVHD $(276,277)$. These expanded NK cells had increased cytotoxicity and cytokine production without exhaustion. When combining membrane-bound IL-21 expansion with IL-18, IL-15, and IL-12, NK cells had increased expression of IFN $\gamma$ and TNF $\alpha$. These results indicate IL-21 as a potent agent for improving efficacy of T and NK cells for ACT (278).

IL-2 and IL-21 regulate opposite immune programs (88, 279). However, IL-21 is able to synergize with IL-7 and IL15. For example, IL-15 and IL-21 synergistically promote the expansion $\mathrm{CD}^{+} \mathrm{T}$ cells with a Tscm phenotype and have increased persistence when infused into the host (196). Also, cells stimulated with IL-15 and IL-21 mediated enhanced immunity in mice with melanoma compared to $\mathrm{T}$ cells expanded in the presence of either IL-15 or IL-21 alone (196). Together these cytokines increase the effector molecules and cytokines produced by T cells in vitro $(280,281)$. Likewise, combining IL-7 and IL-21 promotes the expansion of cells with a Tscm phenotype with high CD28 and CD27 expression (241). The synergy between these two cytokines may be due to IL-21 augmenting IL-7-induced expansion of $\mathrm{T}$ cells and by preventing the down regulation of IL-7R $\alpha$, all of which lead to increased immunity in vivo (282). IL-21/IL-7-treated cells have increased proliferation and production of inflammatory cytokines, directing improved lysis of tumor cells (282). These data support the use of cytokines in combination in next generation clinical trials for patients.
As IL-21 prevents T cell differentiation and preserves their naïve-like phenotype, investigators have used this cytokine to generate "younger" CAR T cells. Interestingly, culturing CD19 CD28-CD3ל CARs with IL-21 led to $\mathrm{CAR}^{+} \mathrm{T}$ cell expansion and increased expression of IFN $\gamma$ and granzyme $\mathrm{B}$ (283). Compared to IL-2-treated CARs, IL-21-treated CARs had increased expression of CD45RA, CD62L, CCR7, and CD28. When transferred into mice with leukemia, IL-21-treated CARs had improved tumor control compared to those treated with IL-2 ex vivo (283). Moreover, membrane-bound IL-21 on CAR $\mathrm{T}$ cells recapitulated the effects of soluble IL-21 in culture (283). To improve the activity of CAR T cells, Sabatino et al. isolated naïve $\mathrm{CD}^{+} \mathrm{T}$ cells $\left(\mathrm{CD}^{+} 2 \mathrm{~L}^{+} \mathrm{CD}^{+} 5 \mathrm{RA}^{+} \mathrm{CCR}^{+}\right)$from healthy donors and transduced them with CD19 CD28-CD3ל CAR constructs. During expansion, cells were cultured in IL7, IL-21 and TWS119 (glycogen synthase kinase $3 \beta$ inhibitor), which enriched for Tscm (284). CD19-CAR Tscm had no changes in their transcriptome compared to non-transfected Tscm and were polyfunctional (284). When transferred into mice with leukemia, CD19-CAR Tscm cells were maintained with intraperitoneal injections of IL-15 and displayed improved survival over conventional CD19-CAR T cells (284). This study demonstrates that in vitro cooperation of IL-7, IL-21, and TWS119 and the in vivo functions of IL-15, lead to improved $\mathrm{T}$ cell functionally improving therapeutic outcome in vivo.

\section{TRUCKs: Putting Cytokines to Work in the Tumor Microenvironment}

Engineering CAR T cells with inducible or constitutive cytokine secretion reinforces transferred $\mathrm{T}$ cell function in the host and manipulates the endogenous immune response within the tumor. $\mathrm{T}$ cells redirected for universal cytokine-mediated killing, termed TRUCKs, are such CAR T cells equipped with the expression of IL-2, IL-7, IL-15, or IL-21 $(285,286)$. In a study conducted by Markley and Sadelain, human CD19-CAR T cells were engineered to constitutively express either IL-2, IL-7, IL-15, or IL-21 (285). Using lymphoma model, constitutive expression of the $\gamma c$ cytokines improved antitumor immunity and animal survival. Even though IL-2- and IL-15-expressing TRUCKs led to the upregulation of effector molecules such as granzyme A, TNF $\alpha$ and IFN $\gamma$, TRUCKs that produced IL-7 or IL-21 were most efficacious (285). IL-21-expressing TRUCKs mediated the best overall tumor immunity in mice, demonstrated by their capacity to increase survival. These TRUCKs were found to coexpress CD27 and CD28 and were able to persist long-term in the animals (285). IL-7-expressing TRUCKs mediated improved antitumor immunity, while upregulating Bcl-2 expression and promoting improved cell expansion in vitro compared to IL-2expressing TRUCKs. This preclinical study suggests that IL-7 or IL-21 TRUCKs could be efficacious in patients.

Other research has revealed that cytokines not in the $\gamma c$ cytokine family, such as IL-12 and IL-18, could be efficacious in TRUCK constructs. For example, in ovarian carcinoma xenograft models, MUC-16 ${ }^{\text {ecto }}$-specific second-generation CAR $\mathrm{T}$ cells were engineered to secrete IL-12 which led to 
improved expansion of TRUCKs and a 27 -fold increase in IFN $\gamma$ production compared to non-IL-12-secreting constructs (287). MUC-16 ${ }^{\text {ecto }}$-specific IL-12-secreting TRUCKs had enhanced immunity compared to non-IL-12-secreting CARs in mice with ovarian cancer, leading to near complete survival (287). IL18-secreting TRUCKs have similar benefits to IL-12-secreting TRUCKs with enhanced immunity and increased proliferation in both mice and humans (288). However, IL-18 secretion had preferential effects on $\mathrm{CD}^{+}{ }^{+}$TRUCKs and was able to promote significant $\mathrm{T}$ cell expansion without costimulatory signaling. IL-18-secretion expanded both $\mathrm{CAR}^{+}$and $\mathrm{CAR}^{-}$ $\mathrm{T}$ cells in an antigen-independent manner which could be beneficial in cases of epitope spreading but detrimental for autoimmune manifestations (288). As both IL-12 and IL-18 promote immunity and expansion of TRUCKs, these cytokines could be potential candidates to improve therapy for solid tumors. However, as IL-12 and IL-18 upregulate the expression of several inflammatory cytokines, such as IFN $\gamma$, and have a historic reputation of toxic side effects, administration could further exacerbate CRS already associated with CAR T cell therapy (289-292). Because of these toxic side effects both preclinically and in patients, the $\gamma c$ cytokines, IL-7, Il-15 and IL-21 might prove to be better options for TRUCK therapies. These cytokines have well documented roles in improving cell products for ACT and as shown by Markley and Sadelain, can improve antitumor immunity of TRUCKs. Additionally, IL-7, IL-15, and IL-21 reinforce the essential T cell functions of proliferation, effector function and memory warranting further investigation. Overall, it is clear that further work must be done to investigate whether the $\gamma_{c}$ cytokine-secreting TRUCKs would be beneficial to overcome the suppressive tumor microenvironment. Findings from future work will be instrumental to apply this therapy to patients with solid tumors, as these constructs have been preclinically shown to be efficacious for blood cancers.

\section{Conclusion: Ideal Use for $\gamma \mathrm{c}$ Cytokines in TIL and CAR T Cell Therapy}

In summary, we have discussed how the various $\gamma$ c cytokines play fundamental roles in shaping $\mathrm{T}$ lymphocyte biology. We have also highlighted important preclinical work that reveals their potential for immunotherapy via several modalities: (1) infusion as monotherapies or in combination with adoptive $\mathrm{T}$ cell transfer therapy, (2) ex vivo expansion of TILs and CAR $\mathrm{T}$ cells to generate "younger" more agile cell products, and (3) in vivo constitutive or inducible production by genetically engineered T cells (TRUCKs) to bolster not only the transferred cells but to enhance immune cells in the oppressive tumor microenvironment. While exploration of TRUCKs has been largely preclinical to date, promising results indicate high potential for successful future clinical translation. Though IL-2 is the only currently FDA-approved $\gamma$ c cytokine, it is possible that this cytokine alone may not be ideal for future trials. As depicted in Figure 3, we envision the ideal application of the $\gamma \mathrm{c}$ cytokines for $\mathrm{T}$ cell therapy to involve a combinatorial approach. Based on preclinical work, perhaps the ideal way to

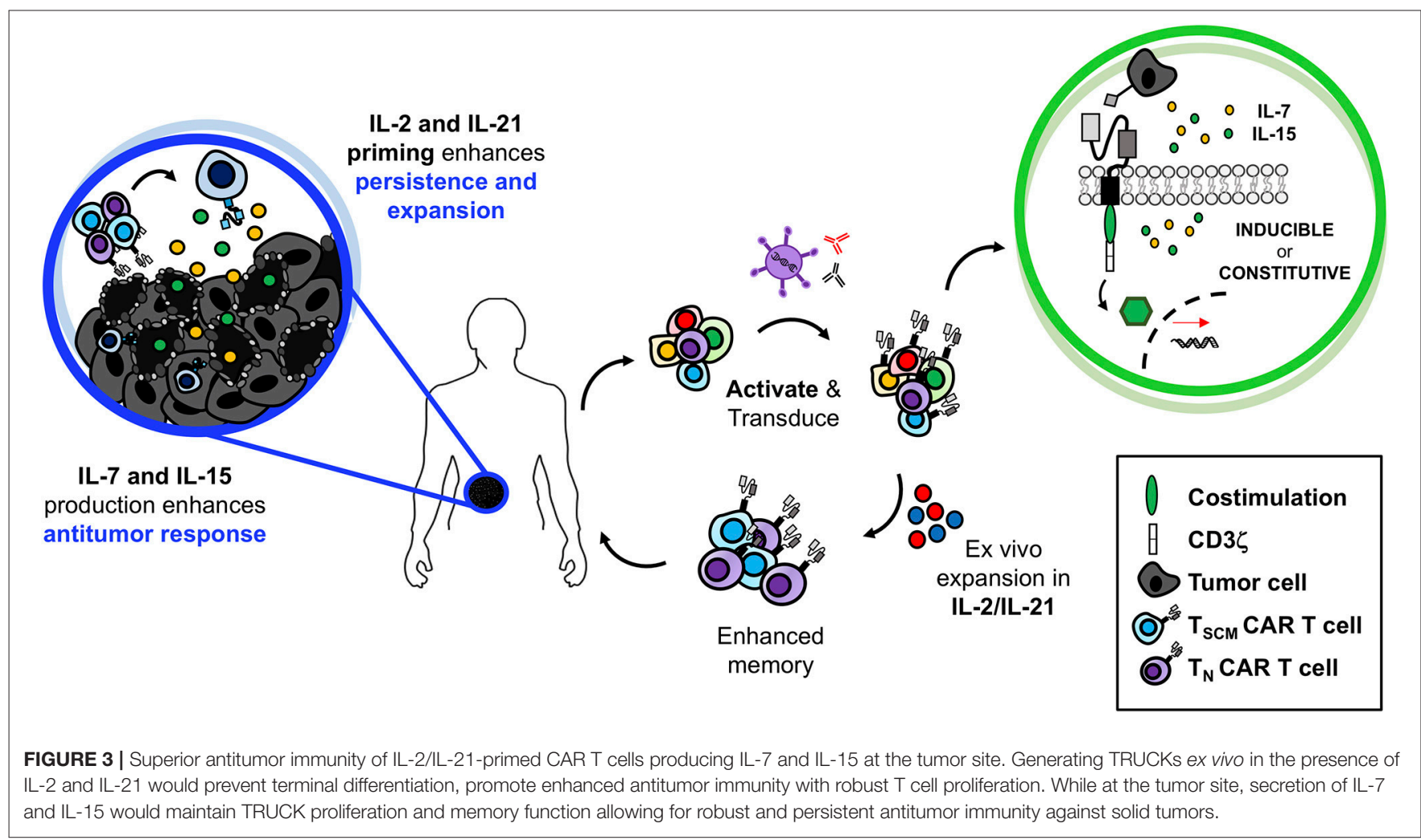


expand T cells ex vivo may require the presence of both IL21 and IL-2. As published by Hinrichs and team in murine T cells, we propose that IL-21 will effectively prevent the terminal differentiation of $\mathrm{T}$ cells while preserving a "younger" phenotype whereas IL-2 will support their expansion to large enough numbers to effectively treat patients (88). Upon administration, we suspect that these IL-21/IL-2-expanded TILs or TRUCKs would be best maintained by engineering them to secrete IL7 and IL-15, which we hypothesize will further promote their persistence and memory recall responses to prevent tumor relapse in patients. The concept portrayed in Figure 3 is just one of many possible ways to combine $\gamma$ c cytokines to bolster $\mathrm{T}$ cell-based therapies. We certainly realize that it is also possible that other cytokine combinations will be important in generating $\mathrm{T}$ cells with long-lived responses to aggressive tumors. Future studies are also necessary to turn off inhibitory signals (such as TGF $\beta$ and IL-10) that dampen T cell responsiveness (293, 294). Regardless, it has become increasingly clear that the $\gamma \mathrm{c}$ cytokine family represents a group of cytokines that support the fundamental attributes $\mathrm{T}$ cells and understanding how to exploit these cytokines for therapeutic use is critical for next generation cancer clinical trials involving vaccines, checkpoint inhibitors and ACT therapy.

\section{REFERENCES}

1. Restifo NP, Dudley ME, Rosenberg SA. Adoptive immunotherapy for cancer: harnessing the T cell response. Nat Rev Immunol. (2012) 12:269-81. doi: $10.1038 /$ nri3191

2. Rosenberg SA, Restifo NP. Adoptive cell transfer as personalized immunotherapy for human cancer. Science (2015) 348:62-68. doi: 10.1126/science.aaa4967

3. Kuwana Y, Asakura Y, Utsunomiya N, Nakanishi M, Arata Y, Itoh S, et al. Expression of chimeric receptor composed of immunoglobulin-derived $\mathrm{V}$ regions and $\mathrm{T}$-cell receptor-derived $\mathrm{C}$ regions. Biochem Biophys Res Commun. (1987) 149:960-8.

4. Gross G, Waks T, Eshhar Z. Expression of immunoglobulin-T-cell receptor chimeric molecules as functional receptors with antibody-type specificity Proc Natl Acad Sci USA. (1989) 86:10024-8.

5. Garrido F, Ruiz-Cabello F, Aptsiauri N. Rejection versus escape: the tumor MHC dilemma. Cancer Immunol Immunother (2017) 66:259-71. doi: 10.1007/s00262-016-1947-x

6. Zhang C, Liu J, Zhong JF, Zhang X. Engineering CAR-T cells. Biomarker Res. (2017) 5:22. doi: 10.1186/s40364-017-0102-y

7. Knochelmann HM, Smith AS, Dwyer CJ, Wyatt MM, Mehrotra S, Paulos CM. CAR T Cells in solid tumors: blueprints for building effective therapies. Front Immunol. (2018) 9:1740. doi: 10.3389/fimmu.2018.01740

8. June $\mathrm{CH}$, Sadelain M. Chimeric antigen receptor therapy. $N$ Engl J Med. (2018) 379:64-73. doi: 10.1056/NEJMra1706169

9. Kochenderfer JN, Wilson WH, Janik JE, Dudley ME, StetlerStevenson M, Feldman SA, et al. Eradication of B-lineage cells and regression of lymphoma in a patient treated with autologous $\mathrm{T}$ cells genetically engineered to recognize CD19. Blood (2010) 116:4099-102. doi: 10.1182/blood-2010-04-281931

10. Kochenderfer JN, Dudley ME, Kassim SH, Somerville RP, Carpenter RO, Stetler-Stevenson M, et al. Chemotherapy-refractory diffuse large B-cell lymphoma and indolent B-cell malignancies can be effectively treated with autologous T cells expressing an anti-CD19 chimeric antigen receptor. J Clin Oncol. (2015) 33:540-9. doi: 10.1200/JCO.2014.56.2025

11. Kochenderfer JN, Dudley ME, Feldman SA, Wilson WH, Spaner DE, Maric I, et al. B-cell depletion and remissions of malignancy along with cytokine-associated toxicity in a clinical trial of anti-CD19

\section{AUTHOR CONTRIBUTIONS}

$\mathrm{CD}$ and $\mathrm{CP}$ conceptualized, wrote and edited the manuscript. $\mathrm{CD}$ and $\mathrm{HK}$ conceptualized and created the figures. HK, AS, MW, GR, DA, EB, ZL, and MR critically reviewed and provided feedback for this manuscript.

\section{FUNDING}

This work was supported by the NIH Training grant T32 AI132164-01 to CD, NIH Training grant T32 GM08716 to HK, R01 CA175061 and R01 CA208514 grants to CP, KL2 South Carolina Clinical and Translational Research grant UL1 TR000062 to CP, ACS-IRG grant 016623-004 to CP and MUSC Start-up funds to CP. Supported in part by pilot research funding, Hollings Cancer Center's Cancer Center Support Grant P30CA138313 at the Medical University of South Carolina.

\section{ACKNOWLEDGMENTS}

We would like to thank the researchers and clinicians for their dedication to improving cancer immunotherapy practices for patients.

chimeric-antigen-receptor-transduced T cells. Blood (2012) 119:2709-20. doi: 10.1182/blood-2011-10-384388

12. Kochenderfer JN, Somerville RPT, Lu T, Shi V, Bot A, Rossi J, et al. Lymphoma remissions caused by anti-CD19 chimeric antigen receptor $\mathrm{T}$ cells are associated with high serum interleukin-15 levels. J Clin Oncol. (2017) 35:1803-13. doi: 10.1200/JCO.2016

13. Schuster SJ, Svoboda J, Chong EA, Nasta SD, Mato AR, Anak O, et al. Chimeric Antigen Receptor T Cells in Refractory B-Cell Lymphomas. N Engl J Med. (2017) 377:2545-54. doi: 10.1056/NEJMoa1708566

14. Neelapu SS, Locke FL, Bartlett NL, Lekakis LJ, Miklos DB, Jacobson CA, et al. Axicabtagene ciloleucel CAR T-cell therapy in refractory large B-Cell lymphoma. N Engl J Med. (2017) 377:2531-44. doi: 10.1056/NEJMoa1707447

15. Lee DW, Kochenderfer JN, Stetler-Stevenson M, Cui YK, Delbrook C, Feldman SA, et al. T cells expressing CD19 chimeric antigen receptors for acute lymphoblastic leukaemia in children and young adults: a phase 1 dose-escalation trial. Lancet (2015) 385:517-28. doi: 10.1016/S0140-6736(14)61403-3

16. Pan J, Yang JF, Deng BP, Zhao XJ, Zhang X, Lin YH, et al. High efficacy and safety of low-dose CD19-directed CAR-T cell therapy in 51 refractory or relapsed B acute lymphoblastic leukemia patients. Leukemia (2017) 31:2587-93. doi: 10.1038/leu.2017.145

17. Brentjens RJ, Riviere I, Park JH, Davila ML, Wang X, Stefanski J, et al. Safety and persistence of adoptively transferred autologous CD19targeted $\mathrm{T}$ cells in patients with relapsed or chemotherapy refractory B-cell leukemias. Blood (2011) 118:4817-28. doi: 10.1182/blood-2011-04348540

18. Park JH, Riviere I, Gonen M, Wang X, Senechal B, Curran KJ, et al. Longterm follow-up of CD19 CAR therapy in acute lymphoblastic leukemia. $N$ Engl J Med. (2018) 378:449-59. doi: 10.1056/NEJMoa1709919

19. Maude SL, Frey N, Shaw PA, Aplenc R, Barrett DM, Bunin NJ, et al. Chimeric antigen receptor $\mathrm{T}$ cells for sustained remissions in leukemia. $N$ Engl J Med. (2014) 371:1507-17. doi: 10.1056/NEJMoa1407222

20. Grupp SA, Kalos M, Barrett D, Aplenc R, Porter DL, Rheingold SR, et al. Chimeric antigen receptor-modified T cells for acute lymphoid leukemia. $N$ Engl J Med. (2013) 368:1509-18. doi: 10.1056/NEJMoa1215134

21. Porter DL, Levine BL, Kalos M, Bagg A, June CH. Chimeric antigen receptormodified T cells in chronic lymphoid leukemia. New Engl J Med. (2011) 365:725-33. doi: 10.1056/NEJMoa1103849 
22. Porter DL, Hwang WT, Frey NV, Lacey SF, Shaw PA, Loren AW, et al. Chimeric antigen receptor $\mathrm{T}$ cells persist and induce sustained remissions in relapsed refractory chronic lymphocytic leukemia. Sci Transl Med. (2015) 7:1-12. doi: 10.1126/scitranslmed.aac5415

23. Davila ML, Riviere I, Wang X, Bartido S, Park J, Curran K, et al. Efficacy and toxicity management of $19-28 \mathrm{z}$ CAR $\mathrm{T}$ cell therapy in B cell acute lymphoblastic leukemia. Sci Transl Med. (2014) 6:1-10. doi: 10.1126/scitranslmed.3008226

24. Bonifant CL, Jackson HJ, Brentjens RJ, Curran KJ. Toxicity and management in CAR T-cell therapy. Mol Ther Oncolytics (2016) 3:16011. doi: $10.1038 /$ mto.2016.11

25. Brudno JN, Kochenderfer JN. Toxicities of chimeric antigen receptor T cells: recognition and management. Blood (2016) 127:3321-3330. doi: 10.1182/blood-2016-04-703751

26. Morgan RA, Yang JC, Kitano M, Dudley ME, Laurencot CM, Rosenberg SA. Case report of a serious adverse event following the administration of T cells transduced with a chimeric antigen receptor recognizing ERBB2. Mol Ther (2010) 18:843-51. doi: 10.1038/mt.2010.24

27. Chang CH, Qiu J, O'Sullivan D, Buck MD, Noguchi T, Curtis JD, et al. Metabolic competition in the tumor microenvironment is a driver of cancer progression. Cell (2015) 162:1229-41. doi: 10.1016/j.cell.2015.08.016

28. Ho PC, Bihuniak JD, Macintyre AN, Staron M, Liu X, Amezquita R, et al. Phosphoenolpyruvate is a metabolic checkpoint of anti-tumor $\mathrm{T}$ cell responses. Cell (2015) 162:1217-28. doi: 10.1016/j.cell.2015.08.012

29. Motz GT, Coukos G. Deciphering and reversing tumor immune suppression. Immunity (2013) 39:61-73. doi: 10.1016/j.immuni.2013.07.005

30. Scarfo I, Maus MV. Current approaches to increase CAR T cell potency in solid tumors: targeting the tumor microenvironment. J Immunother Cancer (2017) 5:28. doi: 10.1186/s40425-017-0230-9

31. Lamers CH, Klaver Y, Gratama JW, Sleijfer S, Debets R. Treatment of metastatic renal cell carcinoma (mRCC) with CAIX CAR-engineered Tcells-a completed study overview. Biochem Soc Trans. (2016) 44:951-9. doi: 10.1042/BST20160037

32. Lamers CH, Sleijfer S, van Steenbergen S, van Elzakker P, van Krimpen B, Groot C, et al. Treatment of metastatic renal cell carcinoma with CAIX CARengineered T cells: clinical evaluation and management of on-target toxicity. Mol Ther. (2013) 21:904-12. doi: 10.1038/mt.2013.17

33. Beatty GL, Haas AR, Maus MV, Torigian DA, Soulen MC, Plesa G, et al. Mesothelin-specific chimeric antigen receptor mRNA-engineered $\mathrm{T}$ cells induce anti-tumor activity in solid malignancies. Cancer Immunol Res. (2014) 2:112-20. doi: 10.1158/2326-6066.CIR-13-0170

34. Ahmed N, Brawley V, Hegde M, Bielamowicz K, Kalra M, Landi D, et al. HER2-Specific chimeric antigen receptor-modified virus-specific T Cells for progressive glioblastoma: a phase 1 dose-escalation trial. JAMA Oncol. (2017) 3:1094-1101. doi: 10.1001/jamaoncol.2017.0184

35. Ahmed N, Brawley VS, Hegde M, Robertson C, Ghazi A, Gerken C, et al. Human Epidermal growth factor receptor 2 (HER2) -specific chimeric antigen receptor-modified T Cells for the immunotherapy of HER2-positive sarcoma. J Clin Oncol. (2015) 33:1688-96. doi: 10.1200/JCO.2014.58.0225

36. Hege KM, Bergsland EK, Fisher GA, Nemunaitis JJ, Warren RS, McArthur JG, et al. Safety, tumor trafficking and immunogenicity of chimeric antigen receptor (CAR)-T cells specific for TAG-72 in colorectal cancer. $J$ Immunother Cancer (2017) 5:22. doi: 10.1186/s40425-017-0222-9

37. Thistlethwaite FC, Gilham DE, Guest RD, Rothwell DG, Pillai M, Burt DJ, et al. The clinical efficacy of first-generation carcinoembryonic antigen (CEACAM5)-specific CAR $\mathrm{T}$ cells is limited by poor persistence and transient pre-conditioning-dependent respiratory toxicity. Cancer Immunol Immunother (2017) 66:1425-36. doi: 10.1007/s00262-017-2034-7

38. Valton J, Guyot V, Boldajipour B, Sommer C, Pertel T, Juillerat A, et al. A Versatile safeguard for chimeric antigen receptor T-cell immunotherapies. Sci Rep. (2018) 8:8972. doi: 10.1038/s41598-018-27264-w

39. Diaconu I, Ballard B, Zhang M, Chen Y, West J, Dotti G, et al. Inducible Caspase-9 Selectively Modulates the Toxicities of CD19-Specific Chimeric Antigen Receptor-Modified T Cells. Mol Ther (2017) 25:580-592. doi: 10.1016/j.ymthe.2017.01.011

40. Phillip B, Kokalaki E, Mekkaoui L, Thomas S, Straathof K, Flutter B, et al. A highly compact epitope-based marker/suicide gene for easier and safer T-cell therapy. Blood (2014) 125:1277-87. doi: 10.1182/blood-2014-01-545020
41. Straathof KC, Pule MA, Yotnda P, Dotti G, Vanin EF, Brenner MK, et al. An inducible caspase 9 safety switch for T-cell therapy. Blood (2005) 105:4247-54. doi: 10.1182/blood-2004-11-4564

42. Di Stasi A, Tey SK, Dotti G, Fujita Y, Kennedy-Nasser A, Martinez C, et al. Inducible apoptosis as a safety swtich for adoptive cell therapy. New Engl J Med. (2011) 365:1673-1683.

43. Malek TR. The biology of interleukin-2. Annu Rev Immunol. (2008) 26:453-479. doi: 10.1146/annurev.immunol.26.021607.090357

44. Gaffen SL. Signaling domains of the interleukin 2 receptor. Cytokine (2001) 14:63-77. doi: 10.1006/cyto.2001.0862

45. Lin JX, Migone TS, Tsang M, Friedmann M, Weatherbee JA, Zhou L et al. The role of shared receptor motifs and common Stat proteins in the generation of cytokine pleiotropy and redundancy by IL-2, IL-4, IL-7, IL-13, and IL-15. Immunity (1995) 2:331-39.

46. Venkitaraman AR, Cowling RJ. Interleukin-7 induces the association of phosphatidylinositol 3-kinase with the alpha chain of the interleukin-7 receptor. Eur J Immunol. (1994) 24:2168-2174. doi: 10.1002/eji.1830240935

47. Franke TF, Kaplan DR, Cantley LC, Toker A. Direct regulation of the Akt proto-oncogene product by phosphatidylinositol-3,4-bisphosphate. Science (1997) 275:665-8.

48. Pallard C, Stegmann AP, van Kleffens T, Smart F, Venkitaraman A, Spits H. Distinct roles of the phosphatidylinositol 3-kinase and STAT5 pathways in IL-7-mediated development of human thymocyte precursors. Immunity (1999) 10:525-35.

49. Jiang Q, Li WQ, Hofmeister RR, Young HA, Hodge DR, Keller JR, et al. Distinct regions of the interleukin-7 receptor regulate different Bcl2 family members. Mol Cell Biol. (2004) 24:6501-13. doi: 10.1128/MCB.24.14.6501-6513.2004

50. Rosenthal LA, Winestock KD, Finbloom DS. IL-2 and IL7 induce heterodimerization of STAT5 isoforms in human peripheral blood T lymphoblasts. Cell Immunol. (1997) 181:172-81. doi: 10.1006/cimm.1997.1208

51. Yu CR, Young HA, Ortaldo JR. Characterization of cytokine differential induction of STAT complexes in primary human T and NK cells. J Leukoc Biol. (1998) 64:245-58.

52. Goswami R, Kaplan MH. A brief history of IL-9. J Immunol (2011) 186:3283-8. doi: 10.4049/jimmunol.1003049

53. Waldmann TA, Dubois S, Tagaya Y. Contrasting roles of IL-2 and IL15 in the life and death of lymphocytes: implications for immunotherapy. Immunity (2001) 14:105-10. doi: 10.1016/S1074-7613(01)00093-0

54. Davis ID, Skak K, Smyth MJ, Kristjansen PE, Miller DM, Sivakumar PV. Interleukin-21 signaling: functions in cancer and autoimmunity. Clin Cancer Res. (2007) 13:6926-32. doi: 10.1158/1078-0432.CCR-07-1238

55. Berglund LJ, Avery DT, Ma CS, Moens L, Deenick EK, Bustamante J, et al. IL-21 signalling via STAT3 primes human naive B cells to respond to IL-2 to enhance their differentiation into plasmablasts. Blood (2013) 122:3940-50. doi: 10.1182/blood-2013-06-506865

56. Witthuhn BA, Silvennoinen O, Miura O, Lai KS, Cwik C, Liu ET, et al. Involvement of the Jak-3 Janus kinase in signalling by interleukins 2 and 4 in lymphoid and myeloid cells. Nature 370:153-7. doi: 10.1038/370153a0

57. Miyazaki T, Kawahara A, Fujii H, Nakagawa Y, Minami Y, Liu ZJ, et al. Functional activation of Jak1 and Jak3 by selective association with IL-2 receptor subunits. Science (1994) 266:1045-7.

58. Wery S, Letourneur M, Bertoglio J, Pierre J. Interleukin-4 induces activation of mitogen-activated protein kinase and phosphorylation of shc in human keratinocytes. J Biol Chem. (1996) 271:8529-8532 .

59. Chen XH, Patel BK, Wang LM, Frankel M, Ellmore N, Flavell RA, et al. Jak1 expression is required for mediating interleukin-4-induced tyrosine phosphorylation of insulin receptor substrate and Stat 6 signaling molecules. J Biol Chem. (1997) 272:6556-6560.

60. Gold MR, Duronio V, Saxena SP, Schrader JW, Aebersold R. Multiple cytokines activate phosphatidylinositol 3-kinase in hemopoietic cells. Association of the enzyme with various tyrosine-phosphorylated proteins. J Biol Chem (1994) 269:5403-12 .

61. Friedrich K, Kammer W, Erhardt I, Brandlein S, Sebald W, Moriggl R. Activation of STAT5 by IL-4 relies on Janus kinase function but not on receptor tyrosine phosphorylation, and can contribute to both cell proliferation and gene regulation. Int Immunol. (1999) 11:1283-94. 
62. Rolling C, Treton D, Pellegrini S, Galanaud P, Richard Y. IL4 and IL13 receptors share the gamma $\mathrm{c}$ chain and activate STAT6, STAT3 and STAT5 proteins in normal human B cells. FEBS Lett. (1996) 393:53-56.

63. Sadlack B, Lohler J, Schorle H, Klebb G, Haber H, Sickel E, et al. Generalized autoimmune disease in interleukin-2-deficient mice is triggered by an uncontrolled activation and proliferation of CD4+ T cells. Eur J Immunol. (1995) 25:3053-9. doi: 10.1002/eji.1830251111

64. Suzuki H, Kundig TM, Furlonger C, Wakeham A, Timms E, Matsuyama $\mathrm{T}$, et al. Deregulated $\mathrm{T}$ cell activation and autoimmunity in mice lacking interleukin-2 receptor beta. Science (1995) 268:1472-6.

65. Willerford DM, Chen J, Ferry JA, Davidson L, Ma A, Alt FW. Interleukin2 receptor alpha chain regulates the size and content of the peripheral lymphoid compartment. Immunity (1995) 3:521-30.

66. Malek TR, Yu A, Vincek V, Scibelli P, Kong L. CD4 regulatory $\mathrm{T}$ cells prevent lethal autoimmunity in IL-2R $\beta$-deficient mice. Implications for the nonredundant function of IL-2. Immunity (2002) 17:167-78. doi: 10.1016/S1074-7613(02)00367-9

67. Yu A, Zhu L, Altman NH, Malek TR. A low interleukin-2 receptor signaling threshold supports the development and homeostasis of T regulatory cells. Immunity (2009) 30:204-17. doi: 10.1016/j.immuni.2008.11.014

68. Antony PA, Paulos CM, Ahmadzadeh M, Akpinarli A, Palmer DC, Sato $\mathrm{N}$, et al. Interleukin-2-dependent mechanisms of tolerance and immunity in vivo. J Immunol. (2006) 176:5255-66. doi: 10.4049/jimmunol.176.9.5255

69. Janas ML, Groves P, Kienzle N, Kelso A. IL-2 regulates perforin and granzyme gene expression in CD8 $+\mathrm{T}$ cells independently of its effects on survival and proliferation. J Immunol. (2005) 175:8003-10. doi: 10.4049/jimmunol.175.12.8003

70. Zhang J, Scordi I, Smyth MJ, Lichtenheld MG. Interleukin 2 receptor signaling regulates the perforin gene through signal transducer and activator of transcription (Stat) 5 activation of two enhancers. J Exp Med. (1999) 190:1297-308

71. Pandiyan P, Zheng L, Ishihara S, Reed J, Lenardo MJ. CD4+CD25+Foxp3+ regulatory $\mathrm{T}$ cells induce cytokine deprivation-mediated apoptosis of effector CD4+ T cells. Nat Immunol. (2007) 8:1353-62. doi: 10.1038/ni1536

72. Toomer KH, Yuan X, Yang J, Dee MJ, Yu A, Malek TR. Developmental progression and interrelationship of central and effector regulatory $\mathrm{T}$ cell subsets. J Immunol. (2016) 196:3665-76. doi: 10.4049/jimmunol.1500595

73. Cheng G, Yuan X, Tsai MS, Podack ER, Yu A, Malek TR. IL-2 receptor signaling is essential for the development of Klrg1+ terminally differentiated $\mathrm{T}$ regulatory cells. J Immunol. (2012) 189:1780-91. doi: 10.4049/jimmunol.1103768

74. Smigiel KS, Richards E, Srivastava S, Thomas KR, Dudda JC, Klonowski KD, et al. CCR7 provides localized access to IL-2 and defines homeostatically distinct regulatory $\mathrm{T}$ cell subsets. J Exp Med. (2014) 211:121-36. doi: 10.1084 /jem. 20131142

75. Lenardo MJ. Interleukin-2 programs alpha beta T lymphocytes for apoptosis. Nature (1991) 353:858-61.

76. Chen W, Jin W, Hardegen N, Lei KJ, Li L, Marinos N, et al. Conversion of peripheral $\mathrm{CD} 4{ }^{+} \mathrm{CD} 25^{-}$naive $\mathrm{T}$ cells to $\mathrm{CD} 4{ }^{+} \mathrm{CD} 25^{+}$regulatory $\mathrm{T}$ cells by TGF-beta induction of transcription factor Foxp3. J Exp Med. (2003) 198:1875-86. doi: 10.1084/jem.20030152

77. Liao W, Lin JX, Wang L, Li P, Leonard WJ. Modulation of cytokine receptors by IL-2 broadly regulates differentiation into helper $\mathrm{T}$ cell lineages. Nat Immunol. (2011) 12:551-9. doi: 10.1038/ni.2030

78. Liao W, Spolski R, Li P, Du N, West EE, Ren M, et al. Opposing actions of IL-2 and IL-21 on Th9 differentiation correlate with their differential regulation of BCL6 expression. Proc Natl Acad Sci USA. (2014) 111:3508-13. doi: $10.1073 /$ pnas.1301138111

79. Cote-Sierra J, Foucras G, Guo L, Chiodetti L, Young HA, Hu-Li J, et al. Interleukin 2 plays a central role in Th2 differentiation. Proc Natl Acad Sci USA. (2004) 101:3880-5. doi: 10.1073/pnas.0400339101

80. Johnston RJ, Choi YS, Diamond JA, Yang JA, Crotty S. STAT5 is a potent negative regulator of TFH cell differentiation. J Exp Med. (2012) 209:243-50. doi: 10.1084/jem.20111174

81. Laurence A, Tato CM, Davidson TS, Kanno Y, Chen Z, Yao Z, et al. Interleukin-2 signaling via STAT5 constrains $\mathrm{T}$ helper 17 cell generation. Immunity (2007) 26:371-81. doi: 10.1016/j.immuni.2007.02.009
82. Bathe OF, Dalyot-Herman N, Malek TR. IL-2 during in vitro priming promotes subsequent engraftment and successful adoptive tumor immunotherapy by persistent memory phenotypic CD8 ${ }^{+} \mathrm{T}$ Cells. J Immunol. (2001) 167:4511-17. doi: 10.4049/jimmunol.167.8.4511

83. Yu A, Zhou J, Marten N, Bergmann CC, Mammolenti M, Levy RB, et al. Efficient Induction of primary and secondary $\mathrm{T}$ Cell-dependent immune responses in vivo in the absence of functional IL-(2003) 2 and IL-15 receptors. J Immunol. 170:236-42. doi: 10.4049/jimmunol.170.1.236

84. Dooms H, Wolslegel K, Lin P, Abbas AK. Interleukin-2 enhances $\mathrm{CD}^{+}{ }^{+} \mathrm{T}$ cell memory by promoting the generation of IL-7R $\alpha$-expressing cells. J Exp Med. (2007) 204:547-57. doi: 10.1084/jem.20062381

85. Williams MA, Tyznik AJ, Bevan MJ. Interleukin-2 signals during priming are required for secondary expansion of $\mathrm{CD}^{+}$memory T cells. Nature (2006) 441:890-3. doi: 10.1038/nature04790

86. Castro I, Yu A, Dee MJ, Malek TR. The basis of distinctive IL-2- and IL15-dependent signaling: weak CD122-dependent signaling favors $\mathrm{CD} 8^{+} \mathrm{T}$ central-memory cell survival but not T effector-memory cell development. $J$ Immunol. (2011) 187:5170-82. doi: 10.4049/jimmunol.1003961

87. Pipkin ME, Sacks JA, Cruz-Guilloty F, Lichtenheld MG, Bevan MJ, Rao A. Interleukin-2 and inflammation induce distinct transcriptional programs that promote the differentiation of effector cytolytic T cells. Immunity (2010) 32:79-90. doi: 10.1016/j.immuni.2009.11.012

88. Hinrichs CS, Spolski R, Paulos CM, Gattinoni L, Kerstann KW, Palmer DC, et al. IL-2 and IL-21 confer opposing differentiation programs to $\mathrm{CD}^{+} \mathrm{T}$ cells for adoptive immunotherapy. Blood (2008) 111:5326-33. doi: 10.1182/blood-2007-09-113050

89. Kalia V, Sarkar S, Subramaniam S, Haining WN, Smith KA, Ahmed R. Prolonged interleukin-2R $\alpha$ expression on virus-specific $\mathrm{CD}^{+}{ }^{+} \mathrm{T}$ cells favors terminal-effector differentiation in vivo. Immunity (2010) 32:91-103. doi: 10.1016/j.immuni.2009.11.010

90. Chen $\mathrm{H}$, Paul WE. Cultured $\mathrm{NK} 1.1^{+} \mathrm{CD} 4^{+} \mathrm{T}$ cells produce large amounts of IL-4 and IFN-gamma upon activation by anti-CD3 or CD1. J Immunol. (1997) 159:2240-49.

91. Brown MA, Pierce JH, Watson CJ, Falco J, Ihle JN, Paul WE. B cell stimulatory factor-1/interleukin-4 mRNA is expressed by normal and transformed mast cells. Cell (1987) 50:809-18.

92. Min B, Prout M, Hu-Li J, Zhu J, Jankovic D, Morgan ES, et al. Basophils produce IL-4 and accumulate in tissues after infection with a Th2inducing parasite. J Exp Med. (2004) 200:507-17. doi: 10.1084/jem.2004 0590

93. Khodoun MV, Orekhova T, Potter C, Morris S, Finkelman FD. Basophils initiate IL-4 production during a memory T-dependent response. J Exp Med. (2004) 200:857-70. doi: 10.1084/jem.20040598

94. Cunningham AF, Serre K, Toellner KM, Khan M, Alexander J, Brombacher $\mathrm{F}$, et al. Pinpointing IL-4-independent acquisition and IL-4-influenced maintenance of Th2 activity by CD4 T cells. Eur J Immunol. (2004) 34:686-94. doi: 10.1002/eji.200324510

95. Noben-Trauth N, Shultz LD, Brombacher F, Urban JFJr, Gu H, Paul WE. An interleukin 4 (IL-4)-independent pathway for $\mathrm{CD}^{+}$T cell IL-4 production is revealed in IL-4 receptor-deficient mice. Proc Natl Acad Sci USA. (1997) 94:10838-43.

96. Ben-Sasson SZ, Le Gros G, Conrad DH, Finkelman FD, Paul WE. IL-4 production by $\mathrm{T}$ cells from naive donors. IL-2 is required for IL-4 production. J Immunol. (1990) 145:1127-36.

97. Qiu Y, Nguyen KD, Odegaard JI, Cui X, Tian X, Locksley RM, et al. Eosinophils and type 2 cytokine signaling in macrophages orchestrate development of functional beige fat. Cell (2014) 157:1292-308. doi: 10.1016/j.cell.2014.03.066

98. Yusuf I, Kageyama R, Monticelli L, Johnston RJ, Ditoro D, Hansen K, et al. Germinal center $\mathrm{T}$ follicular helper cell IL-4 production is dependent on signaling lymphocytic activation molecule receptor (CD150). J Immunol. (2010) 185:190-202. doi: 10.4049/jimmunol.0903505

99. Ohara J, Paul WE. Up-regulation of interleukin 4/B-cell stimulatory factor 1 receptor expression. Proc Natl Acad Sci USA. (1988) 85:8221-25.

100. Letzelter F, Wang Y, Sebald W. The interleukin-4 site-2 epitope determining binding of the common receptor gamma chain. Eur J Biochem. (1998) 257:11-20. 
101. Nelms K, Keegan AD, Zamorano J, Ryan JJ, Paul WE. The IL-4 receptor: signaling mechanisms and biologic functions. Annu Rev Immunol. (1999) 17:701-38. doi: 10.1146/annurev.immunol.17.1.701

102. Obiri NI, Hillman GG, Haas GP, Sud S, Puri RK. Expression of high affinity interleukin-4 receptors on human renal cell carcinoma cells and inhibition of tumor cell growth in vitro by interleukin-4. J Clin Invest. (1993) 91:88-93. doi: 10.1172/JCI116205

103. Obiri NI, Siegel JP, Varricchio F, Puri RK. Expression of high-affinity IL-4 receptors on human melanoma, ovarian and breast carcinoma cells. Clin Exp Immunol. (1994) 95:148-55.

104. Puri RK, Leland P, Kreitman RJ, Pastan I. Human neurological cancer cells express interleukin-4 (IL-4) receptors which are targets for the toxic effects of IL4-Pseudomonas exotoxin chimeric protein. Int J Cancer (1994) 58:574-81.

105. Conticello C, Pedini F, Zeuner A, Patti M, Zerilli M, Stassi G, et al. IL4 protects tumor cells from anti-CD95 and chemotherapeutic agents via up-regulation of antiapoptotic proteins. J Immunol. (2004) 172:5467-77.

106. Kawakami K, Leland P, Puri RK. Structure, function, and targeting of interleukin 4 receptors on human head and neck cancer cells. Cancer Res. (2000) 60:2981-7.

107. Kawakami M, Kawakami K, Stepensky VA, Maki RA, Robin H, Muller W, et al. Interleukin 4 receptor on human lung cancer: a molecular target for cytotoxin therapy. Clin Cancer Res. (2002) 8:3503-11.

108. Gooch JL, Lee AV, Yee D. Interleukin 4 inhibits growth and induces apoptosis in human breast cancer cells. Cancer Res. (1998) 58:4199-205.

109. Volpert OV, Fong T, Koch AE, Peterson JD, Waltenbaugh C, Tepper RI, et al. Inhibition of angiogenesis by interleukin 4. J Exp Med. (1998) 188:1039-46.

110. Gaggianesi M, Turdo A, Chinnici A, Lipari E, Apuzzo T, Benfante A, et al. IL4 primes the dynamics of breast cancer progression via DUSP4 inhibition. Cancer Res. (2017) 77:3268-79. doi: 10.1158/0008-5472.CAN-16-3126

111. Dardalhon V, Awasthi A, Kwon H, Galileos G, Gao W, Sobel RA, et al. IL-4 inhibits TGF-beta-induced Foxp3 ${ }^{+}$T cells and, together with TGFbeta, generates IL- $9^{+}$IL-10 $0^{+}$Foxp3 ${ }^{-}$effector T cells. Nat Immunol. (2008) 9:1347-55. doi: 10.1038/ni.1677

112. Veldhoen M, Uyttenhove C, van Snick J, Helmby H, Westendorf A, Buer J, et al. Transforming growth factor-beta 'reprograms' the differentiation of $\mathrm{T}$ helper 2 cells and promotes an interleukin 9-producing subset. Nat Immunol. (2008) 9:1341-6. doi: 10.1038/ni.1659

113. Mackall CL, Fry TJ, Gress RE. Harnessing the biology of IL-7 for therapeutic application. Nat Rev Immunol. (2011) 11:330-42. doi: 10.1038/nri2970

114. Onder L, Narang P, Scandella E, Chai Q, Iolyeva M, Hoorweg K, et al. IL-7producing stromal cells are critical for lymph node remodeling. Blood (2012) 120:4675-83. doi: 10.1182/blood-2012-03-416859

115. Link A, Vogt TK, Favre S, Britschgi MR, Acha-Orbea H, Hinz B, et al. Fibroblastic reticular cells in lymph nodes regulate the homeostasis of naive T cells. Nat Immunol. (2007) 8:1255-1265. doi: 10.1038/ni1513

116. von Freeden-Jeffry U, Vieira P, Lucian LA, McNeil T, Burdach SE, Murray R. Lymphopenia in interleukin (IL)-7 gene-deleted mice identifies IL-7 as a nonredundant cytokine. J Exp Med. (1995) 181:1519-26.

117. Peschon JJ, Morrissey PJ, Grabstein KH, Ramsdell FJ, Maraskovsky E, Gliniak BC, et al. Early lymphocyte expansion is severely impaired in interleukin 7 receptor-deficient mice. J Exp Med. (1994) 180:1955-60.

118. Puel A, Ziegler SF, Buckley RH, Leonard WJ. Defective IL7R expression in T-B ${ }^{+} \mathrm{NK}^{+}$severe combined immunodeficiency. Nat Genet. (1998) 20:394-7. doi: $10.1038 / 3877$

119. Schluns KS, Kieper WC, Jameson SC, Lefrancois L. Interleukin-7 mediates the homeostasis of naive and memory CD8 T cells in vivo. Nat Immunol. (2000) 1:426-32. doi: 10.1038/80868

120. Tan JT, Dudl E, LeRoy E, Murray R, Sprent J, Weinberg KI, et al. IL-7 is critical for homeostatic proliferation and survival of naive T cells. Proc Natl Acad Sci USA. (2001) 98:8732-7. doi: 10.1073/pnas.161126098

121. Huster KM, Busch V, Schiemann M, Linkemann K, Kerksiek KM, Wagner $\mathrm{H}$, et al. Selective expression of IL-7 receptor on memory T cells identifies early CD40L-dependent generation of distinct $\mathrm{CD} 8^{+}$memory $\mathrm{T}$ cell subsets. Proc Natl Acad Sci USA. (2004) 101:5610-15. doi: 10.1073/pnas.0308054101

122. Jaleco S, Swainson L, Dardalhon V, Burjanadze M, Kinet S, Taylor N. Homeostasis of naive and memory $\mathrm{CD} 4^{+} \mathrm{T}$ cells: IL-2 and IL-7 differentially regulate the balance between proliferation and Fas-mediated apoptosis. J Immunol (2003) 171:61-8. doi: 10.4049/jimmunol.171.1.61
123. Rathmell JC, Farkash EA, Gao W, Thompson CB. IL-7 enhances the survival and maintains the size of naive T cells. J Immunol. (2001) 167:6869-76. doi: 10.4049/jimmunol.167.12.6869

124. Kimura MY, Pobezinsky LA, Guinter TI, Thomas J, Adams A, Park JH, et al. IL-7 signaling must be intermittent, not continuous, during $\mathrm{CD} 8^{+} \mathrm{T}$ cell homeostasis to promote cell survival instead of cell death. Nat Immunol. (2013) 14:143-51. doi: 10.1038/ni.2494

125. Xue HH, Kovanen PE, Pise-Masison CA, Berg M, Radovich MF, Brady JN, et al. IL-2 negatively regulates IL-7 receptor alpha chain expression in activated T lymphocytes. Proc Natl Acad Sci USA. (2002) 99:13759-64. doi: 10.1073/pnas.212214999

126. Park JH, Yu Q, Erman B, Appelbaum JS, Montoya-Durango D, Grimes HL, et al. Suppression of IL7R $\alpha$ transcription by IL-7 and other prosurvival cytokines: a novel mechanism for maximizing IL-7-dependent $\mathrm{T}$ cell survival. Immunity (2004) 21:289-302. doi: 10.1016/j.immuni.2004.07.016

127. Li J, Huston G, Swain SL. IL-7 promotes the transition of CD4 effectors to persistent memory cells. J Exp Med. (2003) 198:1807-1815. doi: $10.1084 /$ jem. 20030725

128. Ouyang W, Beckett O, Flavell RA, Li MO. An essential role of the Forkheadbox transcription factor Foxo1 in control of T cell homeostasis and tolerance. Immunity (2009) 30:358-71. doi: 10.1016/j.immuni.2009.02.003

129. Carrio R, Rolle CE, Malek TR. Non-redundant role for IL-7R signaling for the survival of $\mathrm{CD}^{+}$memory T cells. Eur J Immunol. (2007) 37:3078-88. doi: 10.1002/eji.200737585

130. Kim K, Lee CK, Sayers TJ, Muegge K, Durum SK. The trophic action of IL-7 on pro-T cells: inhibition of apoptosis of pro-T1, -T2, and -T3 cells correlates with Bcl-2 and Bax levels and is independent of Fas and p53 pathways. J Immunol. (1998) 160:5735-41.

131. Akashi K, Kondo M, von Freeden-Jeffry U, Murray R, Weissman IL. Bcl-2 rescues T lymphopoiesis in interleukin-7 receptor-deficient mice. Cell (1997) 89:1033-41.

132. Seddiki N, Santner-Nanan B, Martinson J, Zaunders J, Sasson S, Landay A, et al. Expression of interleukin (IL)-2 and IL-7 receptors discriminates between human regulatory and activated T cells. J Exp Med. (2006) 203:1693-700. doi: 10.1084/jem.20060468

133. Liu W, Putnam AL, Xu-Yu Z, Szot GL, Lee MR, Zhu S, et al. CD127 expression inversely correlates with FoxP3 and suppressive function of human $\mathrm{CD}^{+} \mathrm{T}$ reg cells. J Exp Med (2006) 203:1701-11. doi: $10.1084 /$ jem.20060772

134. Petit-Frere C, Dugas B, Braquet P, Mencia-Huerta JM. Interleukin-9 potentiates the interleukin-4-induced IgE and IgG1 release from murine B lymphocytes. Immunology (1993) 79:146-51.

135. Vink A, Warnier G, Brombacher F, Renauld JC. Interleukin 9-induced in vivo expansion of the B-1 lymphocyte population. J Exp Med. (1999) 189:1413-23.

136. Renauld JC, Goethals A, Houssiau F, Van Roost E, Van Snick J. Cloning and expression of a cDNA for the human homolog of mouse $\mathrm{T}$ cell and mast cell growth factor P40. Cytokine (1990) 2:9-12.

137. Van Snick J, Goethals A, Renauld JC, Van Roost E, Uyttenhove C, Rubira MR, et al. Cloning and characterization of a cDNA for a new mouse $\mathrm{T}$ cell growth factor (P40). J Exp Med. (1989) 169:363-8.

138. Hultner L, Druez C, Moeller J, Uyttenhove C, Schmitt E, Rude E, et al. Mast cell growth-enhancing activity (MEA) is structurally related and functionally identical to the novel mouse T cell growth factor P40/TCGFIII (interleukin 9). Eur J Immunol. (1990) 20:1413-6. doi: 10.1002/eji.1830200632

139. Uyttenhove C, Simpson RJ, Van Snick J. Functional and structural characterization of $\mathrm{P} 40$, a mouse glycoprotein with T-cell growth factor activity. Proc Natl Acad Sci USA. (1988) 85:6934-8.

140. Schmitt E, Van Brandwijk R, Van Snick J, Siebold B, Rude E. TCGF III/P40 is produced by naive murine $\mathrm{CD} 4^{+} \mathrm{T}$ cells but is not a general T cell growth factor. Eur J Immunol. (1989) 19:2167-70. doi: 10.1002/eji.1830191130

141. Stassen M, Arnold M, Hultner L, Muller C, Neudorfl C, Reineke T, et al. Murine bone marrow-derived mast cells as potent producers of IL-9: costimulatory function of IL-10 and kit ligand in the presence of IL-1. J Immunol. (2000) 164:5549-55. doi: 10.4049/jimmunol.164.11.5549

142. Hultner L, Kolsch S, Stassen M, Kaspers U, Kremer JP, Mailhammer R, et al. In activated mast cells IL-1 up-regulates the production of several Th2-related cytokines including IL-9. J Immunol. (2000) 164:5556-63. doi: 10.4049/jimmunol.164.11.5556 
143. Beriou G, Bradshaw EM, Lozano E, Costantino CM, Hastings WD, Orban T, et al. TGF-beta induces IL-9 production from human Th17 cells. J Immunol. (2010) 185:46-54. doi: 10.4049/jimmunol.1000356

144. Elyaman W, Bradshaw EM, Uyttenhove C, Dardalhon V, Awasthi A, Imitola J, et al. IL-9 induces differentiation of TH17 cells and enhances function of FoxP3 ${ }^{+}$natural regulatory T cells. Proc Natl Acad Sci USA. (2009) 106:12885-90. doi: 10.1073/pnas.0812530106

145. Kaplan MH, Hufford MM, Olson MR. The development and in vivo function of T helper 9 cells. Nat Rev Immunol. (2015) 15:295-307. doi: $10.1038 /$ nri3824

146. Druez C, Coulie P, Uyttenhove C, Van Snick J. Functional and biochemical characterization of mouse P40/IL-9 receptors. J Immunol. (1990) 145:2494-9.

147. Townsend JM, Fallon GP, Matthews JD, Smith P, Jolin EH, McKenzie NA. IL-9-deficient mice establish fundamental roles for IL-9 in pulmonary mastocytosis and goblet cell hyperplasia but not $\mathrm{T}$ cell development. Immunity (2000) 13:573-83. doi: 10.1016/S1074-7613(00)00056-X

148. Nowak EC, Weaver CT, Turner H, Begum-Haque S, Becher B, Schreiner B, et al. IL-9 as a mediator of Th17-driven inflammatory disease. J Exp Med. (2009) 206:1653-60. doi: 10.1084/jem.20090246

149. Li J, Chen S, Xiao X, Zhao Y, Ding W, Li XC. IL-9 and Th9 cells in health and diseases-From tolerance to immunopathology. Cytokine Growth Factor Rev. (2017) 37:47-55. doi: 10.1016/j.cytogfr.2017.07.004

150. Knoops L, Renauld JC. IL-9 and its receptor: from signal transduction to tumorigenesis. Growth Factors (2004) 22:207-15. doi: $10.1080 / 08977190410001720879$

151. Lv X, Feng L, Ge X, Lu K, Wang X. Interleukin-9 promotes cell survival and drug resistance in diffuse large B-cell lymphoma. J Exp Clin Cancer Res. (2016) 35:106. doi: 10.1186/s13046-016-0374-3

152. Hu B, Qiu-Lan H, Lei RE, Shi C, Jiang HX, Qin SY. Interleukin9 promotes pancreatic cancer cells proliferation and migration via the miR-200a/beta-catenin axis. BioMed Res Int. (2017) 2017:2831056. doi: $10.1155 / 2017 / 2831056$

153. Lu Y, Hong B, Li H, Zheng Y, Zhang M, Wang S, et al. Tumor-specific IL9-producing $\mathrm{CD}_{8}^{+} \mathrm{Tc}$ 9 cells are superior effector than type-I cytotoxic Tc1 cells for adoptive immunotherapy of cancers. Proc Natl Acad Sci USA. (2014) 111:2265-70. doi: 10.1073/pnas.1317431111

154. Lu Y, Hong S, Li H, Park J, Hong B, Wang L, et al. Th9 cells promote antitumor immune responses in vivo. J Clin Invest. (2012) 122:4160-71. doi: 10.1172/JCI65459

155. Lu Y, Wang Q, Xue G, Bi E, Ma X, Wang A, et al. Th9 cells represent a unique subset of $\mathrm{CD} 4^{+} \mathrm{T}$ cells endowed with the ability to eradicate advanced tumors. Cancer Cell (2018) 33:1048-60.e1047. doi: 10.1016/j.ccell.2018.05.004

156. Purwar R, Schlapbach C, Xiao S, Kang HS, Elyaman W, Jiang X, et al. Robust tumor immunity to melanoma mediated by interleukin-9-producing $\mathrm{T}$ cells. Nat Med. (2012) 18:1248-53. doi: 10.1038/nm.2856

157. Vegran F, Berger H, Boidot R, Mignot G, Bruchard M, Dosset M, et al. The transcription factor IRF1 dictates the IL-21-dependent anticancer functions of TH9 cells. Nat Immunol. (2014) 15:758-66. doi: 10.1038/ni. 2925

158. Dubois S, Mariner J, Waldmann TA, Tagaya Y. IL-15R $\alpha$ recycles and presents IL-15 In trans to neighboring cells. Immunity (2002) 17:537-47. doi: 10.1016/S1074-7613(02)00429-6

159. Pilipow K, Roberto A, Roederer M, Waldmann TA, Mavilio D, Lugli E. IL15 and T-cell Stemness in T-cell-based cancer immunotherapy. Cancer Res. (2015) 75:5187-93. doi: 10.1158/0008-5472.CAN-15-1498

160. Carson WE, Ross ME, Baiocchi RA, Marien MJ, Boiani N, Grabstein $\mathrm{K}$, et al. Endogenous production of interleukin 15 by activated human monocytes is critical for optimal production of interferon-gamma by natural killer cells in vitro. J Clin Invest. (1995) 96:2578-82. doi: 10.1172/JCI11 8321

161. Jonuleit H, Wiedemann K, Muller G, Degwert J, Hoppe U, Knop J, et al. Induction of IL-15 messenger RNA and protein in human blood-derived dendritic cells: a role for IL-15 in attraction of T cells. J Immunol. (1997) 158:2610-15.

162. Doherty TM, Seder RA, Sher A. Induction and regulation of IL-15 expression in murine macrophages. J Immunol. (1996) 156:735-41.
163. Becker TC, Wherry EJ, Boone D, Murali-Krishna K, Antia R, Ma A, et al. Interleukin 15 is required for proliferative renewal of virus-specific memory CD8 T cells. J Exp Med. (2002) 195:1541-8. doi: 10.1084/jem.20020369

164. Kennedy MK, Glaccum M, Brown SN, Butz EA, Viney JL, Embers $\mathrm{M}$, et al. Reversible defects in natural killer and memory CD8 T cell lineages in interleukin 15-deficient mice. J Exp Med. (2000) 191:771-80. doi: 10.1084/jem.191.5.771

165. Sandau MM, Kohlmeier JE, Woodland DL, Jameson SC. IL-15 regulates both quantitative and qualitative features of the memory CD8 $\mathrm{T}$ cell pool. J Immunol. (2010) 184:35-44. doi: 10.4049/jimmunol.0803355

166. Carson WE, Fehniger TA, Haldar S, Eckhert K, Lindemann MJ, Lai CF, et al. A potential role for interleukin-15 in the regulation of human natural killer cell survival. J Clin Invest. (1997) 99:937-43. doi: 10.1172/JCI1 19258

167. Zhang X, Sun S, Hwang I, Tough DF, Sprent J. Potent and selective stimulation of memory-phenotype $\mathrm{CD} 8^{+} \mathrm{T}$ cells in vivo by IL-15. Immunity (1998) 8:591-9.

168. Ku CC, Murakami M, Sakamoto A, Kappler J, Marrack P. Control of homeostasis of $\mathrm{CD} 8{ }^{+}$memory T cells by opposing cytokines. Science (2000) 288:675-8. doi: 10.1126/science.288.5466.675

169. Schluns KS, Klonowski KD, Lefrancois L. Transregulation of memory CD8 T-cell proliferation by IL-15R $\alpha+$ bone marrow-derived cells. Blood (2004) 103:988-94. doi: 10.1182/blood-2003-08-2814

170. Marks-Konczalik J, Dubois S, Losi JM, Sabzevari H, Yamada N, Feigenbaum L, et al. IL-2-induced activation-induced cell death is inhibited in IL15 transgenic mice. Proc Natl Acad Sci USA. (2000) 97:11445-50. doi: 10.1073/pnas.200363097

171. Pelletier M, Ratthe C, Girard D. Mechanisms involved in interleukin15-induced suppression of human neutrophil apoptosis: role of the antiapoptotic Mcl-1 protein and several kinases including Janus kinase-2, p38 mitogen-activated protein kinase and extracellular signal-regulated kinases1/2. FEBS Lett. (2002) 532:164-70. doi: 10.1016/S0014-5793(02)03668-2

172. Huntington ND, Puthalakath H, Gunn P, Naik E, Michalak EM, Smyth MJ, et al. Interleukin 15-mediated survival of natural killer cells is determined by interactions among Bim Noxa and Mcl-1. Nat Immunol. (2007) 8:856-63. doi: $10.1038 /$ ni1 1487

173. Berard M, Brandt K, Bulfone-Paus S, Tough DF. IL-15 promotes the survival of naive and memory phenotype $\mathrm{CD}^{+} \mathrm{T}$ cells. J Immunol. (2003) 170:5018-26. doi: 10.4049/jimmunol.170.10.5018

174. Wensveen FM, Lenartic M, Jelencic V, Lemmermann NA, ten Brinke A, Jonjic S, et al. NKG2D induces Mcl-1 expression and mediates survival of CD8 memory T cell precursors via phosphatidylinositol 3-kinase. J Immunol. (2013) 191:1307-15. doi: 10.4049/jimmunol.1300670

175. Lodolce JP, Boone DL, Chai S, Swain RE, Dassopoulos T, Trettin S, et al. IL-15 receptor maintains lymphoid homeostasis by supporting lymphocyte homing and proliferation. Immunity (1998) 9:669-76.

176. Ben Ahmed M, Belhadj Hmida N, Moes N, Buyse S, Abdeladhim M, Louzir $\mathrm{H}$, et al. IL-15 renders conventional lymphocytes resistant to suppressive functions of regulatory $\mathrm{T}$ cells through activation of the phosphatidylinositol 3-kinase pathway. J Immunol. (2009) 182:6763-70. doi: $10.4049 /$ jimmunol.0801792

177. Perna SK, De Angelis B, Pagliara D, Hasan ST, Zhang L, Mahendravada A, et al. Interleukin 15 provides relief to CTLs from regulatory T cell-mediated inhibition: implications for adoptive $\mathrm{T}$ cell-based therapies for lymphoma. Clin Cancer Res. (2013) 19:106-17. doi: 10.1158/1078-0432.CCR-12-2143

178. Spolski R, Leonard WJ. Interleukin-21: a double-edged sword with therapeutic potential. Nat Rev Drug Discov. (2014) 13:379-95. doi: 10.1038/nrd4296

179. Parrish-Novak J, Dillon SR, Nelson A, Hammond A, Sprecher C, Gross $\mathrm{JA}$, et al. Interleukin 21 and its receptor are involved in NK cell expansion and regulation of lymphocyte function. Nature (2000) 408:57-63. doi: $10.1038 / 35040504$

180. Coquet JM, Kyparissoudis K, Pellicci DG, Besra G, Berzins SP, Smyth MJ, et al. IL-21 is produced by NKT cells and modulates NKT cell activation and cytokine production. J Immunol. (2007) 178:2827-34. doi: 10.4049/jimmunol.178.5.2827

181. Spolski R, Leonard WJ. Interleukin-21: basic biology and implications for cancer and autoimmunity. Annu Rev Immunol. (2008) 26:57-79. doi: 10.1146/annurev.immunol.26.021607.090316 
182. Asao H, Okuyama C, Kumaki S, Ishii N, Tsuchiya S, Foster D, et al. Cutting edge: the common gamma-chain is an indispensable subunit of the IL-21 receptor complex. J Immunol. (2001) 167:1-5. doi: 10.4049/jimmunol.167.1.1

183. Ozaki K, Kikly K, Michalovich D, Young PR, Leonard WJ. Cloning of a type I cytokine receptor most related to the IL-2 receptor beta chain. Proc Natl Acad Sci USA. (2000) 97:11439-11444. doi: 10.1073/pnas.200360997

184. Jin H, Carrio R, Yu A, Malek TR. Distinct activation signals determine whether IL-21 induces B cell costimulation, growth arrest, or Bim-dependent apoptosis. J Immunol. (2004) 173:657-65. doi: 10.4049/jimmunol.173.1.657

185. Wu Z, Kim HP, Xue $\mathrm{HH}$, Liu $\mathrm{H}$, Zhao K, Leonard WJ. Interleukin21 receptor gene induction in human $\mathrm{T}$ cells is mediated by $\mathrm{T}$ cell receptor-induced Sp1 activity. Mol Cell Biol. (2005) 25:9741-52. doi: 10.1128/MCB.25.22.9741-9752.2005

186. Brandt K, Bulfone-Paus S, Foster DC, Ruckert R. Interleukin-21 inhibits dendritic cell activation and maturation. Blood (2003) 102:4090-8. doi: 10.1182/blood-2003-03-0669

187. King C, Ilic A, Koelsch K, Sarvetnick N. Homeostatic expansion of T cells during immune insufficiency generates autoimmunity. Cell (2004) 117:265-77. doi: 10.1016/S0092-8674(04)00335-6

188. Sutherland AP, Joller N, Michaud M, Liu SM, Kuchroo VK, Grusby MJ. IL-21 promotes $\mathrm{CD}^{+}$CTL activity via the transcription factor T-bet. J Immunol. (2013) 190:3977-84. doi: 10.4049/jimmunol.1201730

189. Korn T, Bettelli E, Gao W, Awasthi A, Jager A, Strom TB, et al. IL-21 initiates an alternative pathway to induce proinflammatory $\mathrm{T}(\mathrm{H}) 17$ cells. Nature (2007) 448:484-7. doi: 10.1038/nature05970

190. Nurieva R, Yang XO, Martinez G, Zhang Y, Panopoulos AD, Ma L, et al. Essential autocrine regulation by IL-21 in the generation of inflammatory T cells. Nature (2007) 448:480-3. doi: 10.1038/nature05969

191. Zhou L, Ivanov II, Spolski R, Min R, Shenderov K, Egawa T, et al. IL-6 programs $\mathrm{T}(\mathrm{H})-17$ cell differentiation by promoting sequential engagement of the IL-21 and IL-23 pathways. Nat Immunol. (2007) 8:967-74. doi: $10.1038 /$ ni1488

192. Linterman MA, Beaton L, Yu D, Ramiscal RR, Srivastava M, Hogan JJ, et al. IL-21 acts directly on B cells to regulate Bcl-6 expression and germinal center responses. J Exp Med. (2010) 207:353-63. doi: 10.1084/jem.20091738

193. Bauquet AT, Jin H, Paterson AM, Mitsdoerffer M, Ho IC, Sharpe AH, et al. The costimulatory molecule ICOS regulates the expression of c-Maf and IL-21 in the development of follicular T helper cells and TH-17 cells. Nat Immunol. (2009) 10:167-75. doi: 10.1038/ni.1690

194. Eto D, Lao C, DiToro D, Barnett B, Escobar TC, Kageyama R, et al. IL-21 and IL-6 are critical for different aspects of B cell immunity and redundantly induce optimal follicular helper CD4 T cell (Tfh) differentiation. PLoS ONE (2011) 6:e17739. doi: 10.1371/journal.pone.0017739

195. Mittal A, Murugaiyan G, Beynon V, Hu D, Weiner HL. IL-27 induction of IL21 from human $\mathrm{CD}^{+} \mathrm{T}$ cells induces granzyme B in an autocrine manner. Immunol. Cell Biol. (2012) 90:831-5. doi: 10.1038/icb.2012.14

196. Zeng R, Spolski R, Finkelstein SE, Oh S, Kovanen PE, Hinrichs CS, et al. Synergy of IL-21 and IL-15 in regulating CD8 ${ }^{+} \mathrm{T}$ cell expansion and function. J Exp Med. (2005) 201:139-48. doi: 10.1084/jem.20041057

197. Li Y, Bleakley M, Yee C. IL-21 influences the frequency phenotype, and affinity of the antigen-specific CD8 T cell response. J Immunol. (2005) 175:2261-9. doi: 10.4049/jimmunol.175.4.2261

198. Li Y, Yee C. IL-21 mediated Foxp3 suppression leads to enhanced generation of antigen-specific CD8 ${ }^{+}$cytotoxic T lymphocytes. Blood (2008) 111:229-35. doi: 10.1182/blood-2007-05-089375

199. Frohlich A, Marsland BJ, Sonderegger I, Kurrer M, Hodge MR, Harris $\mathrm{NL}$, et al. IL-21 receptor signaling is integral to the development of Th2 effector responses in vivo. Blood (2007) 109:2023-31. doi: 10.1182/blood-2006-05-021600

200. Suto A, Nakajima H, Hirose K, Suzuki K, Kagami S, Seto Y, et al. Interleukin 21 prevents antigen-induced IgE production by inhibiting germ line C(epsilon) transcription of IL-4-stimulated B cells. Blood (2002) 100:4565-73. doi: 10.1182/blood-2002-04-1115

201. Koreth J, Matsuoka K, Kim HT, McDonough SM, Bindra B, Alyea EP III, et al. Interleukin-2 and regulatory T cells in graft-versus-host disease. $\mathrm{N} \mathrm{Engl}$ J Med. (2011) 365:2055-66. doi: 10.1056/NEJMoa1108188
202. Saadoun D, Rosenzwajg M, Joly F, Six A, Carrat F, Thibault V, et al. Regulatory T-cell responses to low-dose interleukin-2 in HCV-induced vasculitis. N Engl J Med. (2011) 365:2067-77. doi: 10.1056/NEJMoa1105143

203. Rosenzwajg M, Churlaud G, Mallone R, Six A, Derian N, Chaara $\mathrm{W}$, et al. Low-dose interleukin-2 fosters a dose-dependent regulatory $\mathrm{T}$ cell tuned milieu in T1D patients. J Autoimmun. (2015) 58:48-58. doi: 10.1016/j.jaut.2015.01.001

204. Yu A, Snowhite I, Vendrame F, Rosenzwajg M, Klatzmann D, Pugliese A, et al. Selective IL-2 responsiveness of regulatory T cells through multiple intrinsic mechanisms supports the use of low-dose IL-2 therapy in type 1 diabetes. Diabetes (2015) 64:2172-83. doi: 10.2337/db14-1322

205. Fontenot JD, Rasmussen JP, Gavin MA, Rudensky AY. A function for interleukin 2 in Foxp3-expressing regulatory T cells. Nat Immunol. (2005) 6:1142-51. doi: $10.1038 /$ ni1263

206. Rogers WO, Weaver CT, Kraus LA, Li J, Li L, Bucy RP. Visualization of antigen-specific $\mathrm{T}$ cell activation and cytokine expression in vivo. J Immunol. (1997) 158:649-57.

207. Rosenberg SA, Lotze MT, Muul LM, Leitman S, Chang AE, Ettinghausen $\mathrm{SE}$, et al. Observations on the systemic administration of autologous lymphokine-activated killer cells and recombinant interleukin-2 to patients with metastatic cancer. N Engl J Med. (1985) 313:1485-92. doi: 10.1056/NEJM198512053132327

208. Rosenberg SA, Yang JC, Topalian SL, Schwartzentruber DJ, Weber JS, Parkinson DR, et al. Treatment of 283 consecutive patients with metastatic melanoma or renal cell cancer using high-dose bolus interleukin 2. JAMA (1994) 271:907-913.

209. Fyfe G, Fisher RI, Rosenberg SA, Sznol M, Parkinson DR, Louie AC. Results of treatment of 255 patients with metastatic renal cell carcinoma who received high-dose recombinant interleukin-2 therapy. J Clin Oncol. (1995) 13:688-96. doi: 10.1200/JCO.1995.13.3.688

210. Atkins MB, Lotze MT, Dutcher JP, Fisher RI, Weiss G, Margolin K, et al. High-dose recombinant interleukin 2 therapy for patients with metastatic melanoma: analysis of 270 patients treated between 1985 and 1993. J Clin Oncol. (1999) 17:2105. doi: 10.1200/JCO.1999.17.7.2105

211. Wrangle JM, Patterson A, Johnson CB, Neitzke DJ, Mehrotra S, Denlinger $\mathrm{CE}$, et al. IL-2 and beyond in cancer immunotherapy. J Interferon Cytokine Res. (2018) 38:45-68. doi: 10.1089/jir.2017.0101

212. Rosenberg SA. IL-2: the first effective immunotherapy for human cancer. J Immunol. (2014) 192:5451-8. doi: 10.4049/jimmunol.1490019

213. Pachella LA, Madsen LT, Dains JE. The toxicity and benefit of various dosing strategies for interleukin-2 in metastatic melanoma and renal cell carcinoma. J Adv Pract Oncol. (2015) 6:212-21. doi: 10.6004/jadpro.2015.6.3.3

214. Schwartz RN, Stover L, Dutcher JP. Managing toxicities of high-dose interleukin-2. Oncology (Williston Park N.Y.) (2002) 16:11-20.

215. Atkins MB. Interleukin-2: clinical applications. Sem Oncol. (2002) 29:12-17. doi: 10.1053/sonc.2002.33077

216. Krieg C, Letourneau S, Pantaleo G, Boyman O. Improved IL-2 immunotherapy by selective stimulation of IL-2 receptors on lymphocytes and endothelial cells. Proc Natl Acad Sci USA. (2010) 107:11906-11. doi: 10.1073/pnas. 1002569107

217. Levin AM, Bates DL, Ring AM, Krieg C, Lin JT, Su L, et al. Exploiting a natural conformational switch to engineer an interleukin-2 'superkine'. Nature (2012) 484:529-33. doi: 10.1038/nature10975

218. Letourneau S, van Leeuwen EM, Krieg C, Martin C, Pantaleo G, Sprent J, et al. IL-2/anti-IL-2 antibody complexes show strong biological activity by avoiding interaction with IL-2 receptor alpha subunit CD25. Proc Natl Acad Sci USA. (2010) 107:2171-6. doi: 10.1073/pnas.0909384107

219. Boyman O, Kovar M, Rubinstein MP, Surh CD, Sprent J. Selective stimulation of $\mathrm{T}$ cell subsets with antibody-cytokine immune complexes. Science (2006) 311:1924-6. doi: 10.1126/science.1122927

220. Su EW, Moore CJ, Suriano S, Johnson CB, Songalia N, Patterson $A$, et al. IL- $2 \mathrm{R} \alpha$ mediates temporal regulation of IL-2 signaling and enhances immunotherapy. Sci Transl Med (2015) 7:311ra170. doi: 10.1126/scitranslmed.aac8155

221. Sockolosky JT, Trotta E, Parisi G, Picton L, Su LL, Le A.C, et al. Selective targeting of engineered $\mathrm{T}$ cells using orthogonal IL-2 cytokine-receptor complexes. Science (2018) 1037-42. doi: 10.1126/science.aar3246 
222. Dudley ME, Wunderlich JR, Shelton TE, Even J, Rosenberg SA. Generation of tumor-infiltrating lymphocyte cultures for use in adoptive transfer therapy for melanoma patients. J Immunother (2003) 26:332-42.

223. Rosenberg SA, Restifo NP, Yang JC, Morgan RA, Dudley ME. Adoptive cell transfer: a clinical path to effective cancer immunotherapy. Nat Rev Cancer (2008) 8:299-308. doi: 10.1038/nrc2355

224. Quintarelli C, Vera JF, Savoldo B, Giordano Attianese GM, Pule M, Foster $\mathrm{AE}$, et al. Co-expression of cytokine and suicide genes to enhance the activity and safety of tumor-specific cytotoxic T lymphocytes. Blood (2007) 110:2793-802. doi: 10.1182/blood-2007-02-072843

225. Rosenberg SA, Yang JC, Sherry RM, Kammula US, Hughes MS, Phan $\mathrm{GQ}$, et al. Durable complete responses in heavily pretreated patients with metastatic melanoma using T-cell transfer immunotherapy. Clin Cancer Res. (2011) 17:4550-7. doi: 10.1158/1078-0432.CCR-11-0116

226. Heemskerk B, Liu K, Dudley ME, Johnson LA, Kaiser A, Downey S, et al. Adoptive cell therapy for patients with melanoma, using tumor-infiltrating lymphocytes genetically engineered to secrete interleukin-2. Hum Gene Ther. (2008) 19:496-510. doi: 10.1089/hum.2007.0171

227. Liu K, Rosenberg SA. Transduction of an IL-2 gene into human melanomareactive lymphocytes results in their continued growth in the absence of exogenous IL-2 and maintenance of specific antitumor activity. J Immunol. (2001) 167:6356-65. doi: 10.4049/jimmunol.167.11.6356

228. Watanabe K, Luo Y, Da T, Guedan S, Ruella M, Scholler J, et al. Pancreatic cancer therapy with combined mesothelin-redirected chimeric antigen receptor T cells and cytokine-armed oncolytic adenoviruses. JCI Insight (2018) 3:99573. doi: 10.1172/jci.insight.99573

229. Golumba-Nagy V, Kuehle J, Hombach AA, Abken H. CD28-zeta CAR T cells resist TGF-beta repression through IL-2 signaling which Can Be mimicked by an engineered IL-7 autocrine loop. Mol Ther. (2018) 26:2218-30. doi: 10.1016/j.ymthe.2018.07.005

230. Zhang X, Lv X, Song Y. Short-term culture with IL-2 is beneficial for potent memory chimeric antigen receptor $\mathrm{T}$ cell production. Biochem Biophys Res Commun. (2018) 495:1833-8. doi: 10.1016/j.bbrc.2017.12.041

231. Kaartinen T, Luostarinen A, Maliniemi P, Keto J, Arvas M, Belt H, et al. Low interleukin-2 concentration favors generation of early memory $\mathrm{T}$ cells over effector phenotypes during chimeric antigen receptor T-cell expansion. Cytotherapy (2017) 19:689-702. doi: 10.1016/j.jcyt.2017.03.067

232. Kagoya Y, Tanaka S, Guo T, Anczurowski M, Wang CH, Saso K, et al. A novel chimeric antigen receptor containing a JAK-STAT signaling domain mediates superior antitumor effects. Nat Med. (2018) 24:352-9. doi: $10.1038 / \mathrm{nm} .4478$

233. Jicha DL, Mule JJ, Rosenberg SA. Interleukin 7 generates antitumor cytotoxic $\mathrm{T}$ lymphocytes against murine sarcomas with efficacy in cellular adoptive immunotherapy. J Exp Med. (1991) 174:1511-15. doi: 10.1084/jem.174.6.1511

234. Rosenberg SA, Sportes C, Ahmadzadeh M, Fry TJ, Ngo LT, Schwarz SL, et al. IL-7 administration to humans leads to expansion of $\mathrm{CD} 8^{+}$and $\mathrm{CD} 4^{+}$cells but a relative decrease of $\mathrm{CD}^{+}$T-regulatory cells. J Immunother (2006) 29:313-19. doi: 10.1097/01.cji.0000210386.55951.c2

235. Sportes C, Hakim FT, Memon SA, Zhang H, Chua KS, Brown MR, et al. Administration of rhIL-7 in humans increases in vivo TCR repertoire diversity by preferential expansion of naive T cell subsets. J Exp Med. (2008) 205:1701-14. doi: 10.1084/jem.20071681

236. Cieri N, Camisa B, Cocchiarella F, Forcato M, Oliveira G, Provasi E, et al. IL-7 and IL-15 instruct the generation of human memory stem T cells from naive precursors. Blood (2013) 121:573-84. doi: 10.1182/blood-2012-05-431718

237. Gattinoni L, Lugli E, Ji Y, Pos Z, Paulos CM, Quigley MF, et al. A human memory T cell subset with stem cell-like properties. Nat Med. (2011) 17:1290-7. doi: $10.1038 / \mathrm{nm} .2446$

238. Hurton LV, Singh H, Najjar AM, Switzer KC, Mi T, Maiti S, et al. Tethered IL-15 augments antitumor activity and promotes a stem-cell memory subset in tumor-specific T cells. Proc Natl Acad Sci USA. (2016) 113, E7788-97. doi: 10.1073/pnas.1610544113

239. Kondo T, Morita R, Okuzono Y, Nakatsukasa H, Sekiya T, Chikuma S, et al. Notch-mediated conversion of activated $\mathrm{T}$ cells into stem cell memorylike T cells for adoptive immunotherapy. Nat Commun. (2017) 8:15338. doi: $10.1038 /$ ncomms 15338
240. Wu S, Zhu W, Peng Y, Wang L, Hong Y, Huang L, et al. The antitumor effects of vaccine-activated $\mathrm{CD} 8^{+} \mathrm{T}$ cells associate with weak TCR signaling and induction of stem-like memory T cells. Cancer Immunol Res. (2017) 5:908-19. doi: 10.1158/2326-6066.CIR-17-0016

241. Ptackova P, Musil J, Stach M, Lesny P, Nemeckova S, Kral V, et al. A new approach to CAR T-cell gene engineering and cultivation using piggyBac transposon in the presence of IL-4, IL-7 and IL-21. Cytotherapy (2018) 20:507-20. doi: 10.1016/j.jcyt.2017.10.001

242. Gargett T, Brown MP. Different cytokine and stimulation conditions influence the expansion and immune phenotype of third-generation chimeric antigen receptor $\mathrm{T}$ cells specific for tumor antigen GD2. Cytotherapy (2015) 17:487-95. doi: 10.1016/j.jcyt.2014.12.002

243. Carrio R, Bathe OF, Malek TR. Initial Antigen Encounter Programs CD8 ${ }^{+} \mathrm{T}$ cells competent to develop into memory cells that are activated in an antigenfree IL-7- and IL-15-rich environment. J Immunol. (2004) 172:7315-23. doi: 10.4049/jimmunol.172.12.7315

244. Xu Y, Zhang M, Ramos CA, Durett A, Liu E, Dakhova O, et al. Closely related T-memory stem cells correlate with in vivo expansion of CAR.CD19$\mathrm{T}$ cells and are preserved by IL-7 and IL-15. Blood (2014) 123:3750-9. doi: 10.1182/blood-2014-01-552174

245. Bajgain P, Tawinwung S, D'Elia L, Sukumaran S, Watanabe N, Hoyos $\mathrm{V}$, et al. CAR $\mathrm{T}$ cell therapy for breast cancer: harnessing the tumor milieu to drive $\mathrm{T}$ cell activation. I Immunother Cancer (2018) 6:34. doi: 10.1186/s40425-018-0347-5

246. Adachi K, Kano Y, Nagai T, Okuyama N, Sakoda Y, Tamada K. IL-7 and CCL19 expression in CAR-T cells improves immune cell infiltration and CAR-T cell survival in the tumor. Nat Biotechnol. (2018) 36:346-51. doi: $10.1038 /$ nbt. 4086

247. Shum T, Omer B, Tashiro H, Kruse RL, Wagner DL, Parikh K, et al. Constitutive Signaling from an Engineered IL7 receptor promotes durable tumor elimination by tumor-redirected T Cells. Cancer Discov. (2017) 7:1238-47. doi: 10.1158/2159-8290.CD-17-0538

248. Guo Y, Luan L, Patil NK, Sherwood ER. Immunobiology of the IL-15/IL15Ralpha complex as an antitumor and antiviral agent. Cytokine Growth Factor Rev. (2017) 38:10-21. doi: 10.1016/j.cytogfr.2017.08.002

249. Weninger W, Crowley MA, Manjunath N, von Andrian UH. Migratory properties of naive, effector, and memory $\mathrm{CD}^{+} \mathrm{T}$ cells. J Exp Med. (2001) 194:953-66. doi: 10.1084/jem.194.7.953

250. Klebanoff CA, Gattinoni L, Torabi-Parizi P, Kerstann K, Cardones AR, Finkelstein SE, et al. Central memory self/tumor-reactive $\mathrm{CD} 8^{+} \mathrm{T}$ cells confer superior antitumor immunity compared with effector memory T cells. Proc Natl Acad Sci USA. (2005) 102:9571-76. doi: 10.1073/pnas.0503726102

251. Klebanoff CA, Finkelstein SE, Surman DR, Lichtman MK, Gattinoni L, Theoret MR, et al. IL-15 enhances the in vivo antitumor activity of tumorreactive CD8 ${ }^{+}$T cells. Proc Natl Acad Sci USA. (2004) 101:1969-74. doi: 10.1073/pnas.0307298101

252. Zhang M, Yao Z, Dubois S, Ju W, Muller JR, Waldmann TA. Interleukin15 combined with an anti-CD40 antibody provides enhanced therapeutic efficacy for murine models of colon cancer. Proc Natl Acad Sci USA. (2009) 106:7513-18. doi: 10.1073/pnas.0902637106

253. Yu P, Steel JC, Zhang M, Morris JC, Waldmann TA. Simultaneous blockade of multiple immune system inhibitory checkpoints enhances antitumor activity mediated by interleukin-15 in a murine metastatic colon carcinoma model. Clin Cancer Res. (2010) 16:6019-28. doi: 10.1158/1078-0432.CCR-10-1966

254. King JW, Thomas S, Corsi F, Gao L, Dina R, Gillmore R, et al. IL15 can reverse the unresponsiveness of Wilms' tumor antigen-specific CTL in patients with prostate cancer. Clin Cancer Res. (2009) 15:1145-54. doi: 10.1158/1078-0432.CCR-08-1821

255. Teague RM, Sather BD, Sacks JA, Huang MZ, Dossett ML, Morimoto J, et al. Interleukin- 15 rescues tolerant $\mathrm{CD}^{+} \mathrm{T}$ cells for use in adoptive immunotherapy of established tumors. Nat Med. (2006) 12:335-41. doi: $10.1038 / \mathrm{nm} 1359$

256. Oelert T, Papatriantafyllou M, Pougialis G, Hammerling GJ, Arnold $\mathrm{B}$, Schuler T. Irradiation and IL-15 promote loss of CD8 T-cell tolerance in response to lymphopenia. Blood (2010) 115:2196-202. doi: 10.1182/blood-2009-06-227298 
257. Conlon KC, Lugli E, Welles HC, Rosenberg SA, Fojo AT, Morris JC, et al. Redistribution, hyperproliferation, activation of natural killer cells and CD8 T cells, and cytokine production during first-in-human clinical trial of recombinant human interleukin-15 in patients with cancer. J Clin Oncol. (2015) 33:74-82. doi: 10.1200/JCO.2014.57.3329

258. Mortier E, Quemener A, Vusio P, Lorenzen I, Boublik Y, Grotzinger J, et al. Soluble interleukin-15 receptor $\alpha(\mathrm{IL}-15 \mathrm{R} \alpha)$-sushi as a selective and potent agonist of IL-15 action through IL-15R $\beta / \gamma$. Hyperagonist IL-15 x IL-15R $\alpha$ fusion proteins. J Biol Chem. (2006) 281:1612-19. doi: 10.1074/jbc.M508624200

259. Stoklasek TA, Schluns KS, Lefrancois L. Combined IL-15/IL-15R $\alpha$ immunotherapy maximizes IL-15 activity in vivo. J Immunol. (2006) 177:6072-80. doi: 10.4049/jimmunol.177.9.6072

260. Xu W, Jones M, Liu B, Zhu X, Johnson CB, Edwards AC, et al. Efficacy and mechanism-of-action of a novel superagonist interleukin15: interleukin-15 receptor alphaSu/Fc fusion complex in syngeneic murine models of multiple myeloma. Cancer Res. (2013) 73:3075-86. doi: 10.1158/0008-5472.CAN-12-2357

261. Kim PS, Kwilas AR, Xu W, Alter S, Jeng EK, Wong HC, et al. IL-15 superagonist/IL-15RalphaSushi-Fc fusion complex (IL-15SA/IL15RalphaSu-Fc; ALT-803) markedly enhances specific subpopulations of $\mathrm{NK}$ and memory $\mathrm{CD}^{+}{ }^{+} \mathrm{T}$ cells, and mediates potent anti-tumor activity against murine breast and colon carcinomas. Oncotarget (2016) 7:16130-45. doi: 10.18632 /oncotarget. 7470

262. Mathios D, Park CK, Marcus WD, Alter S, Rhode PR, Jeng EK, et al. Therapeutic administration of IL-15 superagonist complex ALT-803 leads to long-term survival and durable antitumor immune response in a murine glioblastoma model. Int J Cancer (2016) 138:187-94. doi: 10.1002/ijc.29686

263. Wrangle JM, Velcheti V, Patel MR, Garrett-Mayer E, Hill EG, Ravenel JG, et al. ALT-803, an IL-15 superagonist, in combination with nivolumab in patients with metastatic non-small cell lung cancer: a nonrandomised, open-label, phase $1 \mathrm{~b}$ trial. Lancet Oncol. (2018) 19:694-704. doi: 10.1016/S1470-2045(18)30148-7

264. Hoyos V, Savoldo B, Quintarelli C, Mahendravada A, Zhang M, Vera J, et al. Engineering CD19-specific T lymphocytes with interleukin-15 and a suicide gene to enhance their anti-lymphoma/leukemia effects and safety. Leukemia (2010) 24:1160-70. doi: 10.1038/leu.2010.75

265. Krenciute G, Prinzing BL, Yi Z, Wu M.-F., Liu H, Dotti G, et al. Transgenic Expression of IL15 Improves Antiglioma Activity of IL13R $\alpha 2$-CAR T Cells but Results in Antigen Loss Variants. Cancer Immunol Res. (2017) 5:571-81. doi: 10.1158/2326-6066.CIR-16-0376

266. Hsu C, Jones SA, Cohen CJ, Zheng Z, Kerstann K, Zhou J, et al. Cytokineindependent growth and clonal expansion of a primary human $\mathrm{CD}^{+} \mathrm{T}$-cell clone following retroviral transduction with the IL-15 gene. Blood (2007) 109:5168-77. doi: 10.1182/blood-2006-06-029173

267. Thompson JA, Curti BD, Redman BG, Bhatia S, Weber JS, Agarwala SS, et al. Phase I study of recombinant interleukin-21 in patients with metastatic melanoma and renal cell carcinoma. J Clin Oncol. (2008) 26:2034-9. doi: 10.1200/JCO.2007.14.5193

268. Davis ID, Brady B, Kefford RF, Millward M, Cebon J, Skrumsager $\mathrm{BK}$, et al. Clinical and biological efficacy of recombinant human interleukin-21 in patients with stage IV malignant melanoma without prior treatment: a phase IIa trial. Clin Cancer Res. (2009) 15:2123-9. doi: 10.1158/1078-0432.CCR-08-2663

269. Petrella TM, Tozer R, Belanger K, Savage KJ, Wong R, Smylie M, et al. Interleukin-21 has activity in patients with metastatic melanoma: a phase II study. J Clin Oncol. (2012) 30:3396-401. doi: 10.1200/JCO.2011.40.0655

270. Klebanoff CA, Scott CD, Leonardi AJ, Yamamoto TN, Cruz AC, Ouyang C, et al. Memory T cell-driven differentiation of naive cells impairs adoptive immunotherapy. J Clin Invest. (2016) 126:318-34. doi: 10.1172/JCI81217

271. Hinrichs CS, Borman ZA, Gattinoni L, Yu Z, Burns WR, Huang J, et al. Human effector $\mathrm{CD} 8^{+} \mathrm{T}$ cells derived from naive rather than memory subsets possess superior traits for adoptive immunotherapy. Blood (2011) 117:808-14. doi: 10.1182/blood-2010-05-286286

272. Zhou X, Xue HH. Cutting edge: generation of memory precursors and functional memory $\mathrm{CD}^{+}{ }^{+} \mathrm{T}$ cells depends on $\mathrm{T}$ cell factor-1 and lymphoid enhancer-binding factor-1. J Immunol. (2012) 189:2722-6. doi: $10.4049 /$ jimmunol.1201150
273. Zhou X, Yu S, Zhao DM, Harty JT, Badovinac VP, Xue HH. Differentiation and persistence of memory $\mathrm{CD} 8^{+} \mathrm{T}$ cells depend on $\mathrm{T}$ cell factor 1 . Immunity (2010) 33:229-240. doi: 10.1016/j.immuni.2010.08.002

274. Santegoets SJ, Turksma AW, Suhoski MM, Stam AG, Albelda SM, Hooijberg E, et al. IL-21 promotes the expansion of $\mathrm{CD} 27^{+} \mathrm{CD} 28^{+}$tumor infiltrating lymphocytes with high cytotoxic potential and low collateral expansion of regulatory T cells. J Transl Med. (2013) 11:37. doi: 10.1186/1479-58 76-11-37

275. Chen Y, Yu F, Jiang Y, Chen J, Wu K, Chen X, et al. Adoptive transfer of interleukin-21-stimulated Human $\mathrm{CD}^{+} \mathrm{T}$ memory stem cells efficiently inhibits tumor growth. J Immunother. (2018) 41:274-83. doi: 10.1097/CJI.0000000000000229

276. Somanchi SS, Lee DA. Ex vivo expansion of human NK cells using K562 engineered to express membrane bound IL21. Methods Mol Biol. (2016) 1441:175-93. doi: 10.1007/978-1-4939-3684-7_15

277. Ciurea SO, Schafer JR, Bassett R, Denman CJ, Cao K, Willis D, et al. Phase 1 clinical trial using mbIL21 ex vivo-expanded donor-derived NK cells after haploidentical transplantation. Blood (2017) 130:1857-68. doi: 10.1182/blood-2017-05-785659

278. Lusty E, Poznanski SM, Kwofie K, Mandur TS, Lee DA, Richards CD, et al. IL-18/IL-15/IL-12 synergy induces elevated and prolonged IFNgamma production by ex vivo expanded NK cells which is not due to enhanced STAT4 activation. Molecular immunology (2017) 88:138-47. doi: 10.1016/j.molimm.2017.06.025

279. Spolski R, Gromer D, Leonard WJ. The gamma c family of cytokines: finetuning signals from IL-2 and IL-21 in the regulation of the immune response. F1000Research (2017) 6:1872. doi: 10.12688/f1000research.12202.1

280. Pouw N, Treffers-Westerlaken E, Kraan J, Wittink F, ten Hagen T, Verweij J, et al. Combination of IL-21 and IL-15 enhances tumour-specific cytotoxicity and cytokine production of TCR-transduced primary T cells. Cancer Immunol Immunother. (2010) 59:921-31. doi: 10.1007/s00262-0100818-0

281. Strengell M, Matikainen S, Siren J, Lehtonen A, Foster D, Julkunen I, et al. IL-21 in synergy with IL-15 or IL-18 enhances IFN- $\gamma$ production in human NK and T cells. J Immunol (2003) 170:5464-9. doi: 10.4049/jimmunol.170.11.5464

282. Liu S, Lizee G, Lou Y, Liu C, Overwijk WW, Wang G, et al. IL-21 synergizes with IL-7 to augment expansion and anti-tumor function of cytotoxic T cells. Int Immunol. (2007) 19:1213-21. doi: 10.1093/intimm/dxm093

283. Singh H, Figliola MJ, Dawson MJ, Huls H, Olivares S, Switzer K, et al. Reprogramming CD19-specific $\mathrm{T}$ cells with IL-21 signaling can improve adoptive immunotherapy of B-lineage malignancies. Cancer Res. (2011) 71:3516-27. doi: 10.1158/0008-5472.CAN-10-3843

284. Sabatino M, Hu J, Sommariva M, Gautam S, Fellowes V, Hocker JD, et al. Generation of clinical-grade CD19-specific CAR-modified CD8 ${ }^{+}$memory stem cells for the treatment of human B-cell malignancies. Blood (2016) 128:519-28. doi: 10.1182/blood-2015-11-683847

285. Markley JC, Sadelain M. IL-7 and IL-21 are superior to IL-2 and IL-15 in promoting human $\mathrm{T}$ cell-mediated rejection of systemic lymphoma in immunodeficient mice. Blood (2010) 115:3508-19. doi: 10.1182/blood-2009-09-241398

286. Chmielewski M, Abken H. TRUCKs: the fourth generation of CARs. Expert Opin Biol Ther. (2015) 15:1145-54. doi: 10.1517/14712598.2015.1046430

287. Koneru M, Purdon TJ, Spriggs D, Koneru S, Brentjens RJ. IL12 secreting tumor-targeted chimeric antigen receptor $\mathrm{T}$ cells eradicate ovarian tumors in vivo. Oncoimmunology (2015) 4:e994446. doi: 10.4161/2162402X.2014.994446

288. Hu B, Ren J, Luo Y, Keith B, Young RM, Scholler J, et al. Augmentation of Antitumor Immunity by Human and Mouse CAR T Cells Secreting IL-18. Cell Rep. (2017) 20:3025-33. doi: 10.1016/j.celrep.2017.09.002

289. Lenzi R, Edwards R, June C, Seiden MV, Garcia ME, Rosenblum M, et al. Phase II study of intraperitoneal recombinant interleukin-12 (rhIL-12) in patients with peritoneal carcinomatosis (residual disease $<1 \mathrm{~cm}$ ) associated with ovarian cancer or primary peritoneal carcinoma. J Transl Med. (2007) 5:66. doi: 10.1186/1479-5876-5-66

290. Maxwell JR, Yadav R, Rossi RJ, Ruby CE, Weinberg AD, Aguila HL, et al. IL-18 bridges innate and adaptive immunity through IFN- $\gamma$ and the CD134 pathway. J Immunol. (2006) 177:234-45. doi: 10.4049/jimmunol.177.1.234 
291. Ju DW, Tao Q, Lou G, Bai M, He L, Yang Y, et al. Interleukin 18 transfection enhances antitumor immunity induced by dendritic cell-tumor cell conjugates. Cancer Res. (2001) 61:3735-40.

292. Nakamura S, Otani T, Ijiri Y, Motoda R, Kurimoto M, Orita K. IFN$\gamma$-dependent and -independent mechanisms in adverse effects caused by concomitant administration of IL-18 and IL-12. J Immunol. (2000) 164:3330-6. doi: 10.4049/jimmunol.164.6.3330

293. Rachidi S, Metelli A, Riesenberg B, Wu BX, Nelson MH, Wallace $\mathrm{C}$, et al. Platelets subvert $\mathrm{T}$ cell immunity against cancer via GARPTGFbeta axis. Sci Immunol. (2017) 2:eaai7911. doi: 10.1126/sciimmunol.aai 7911

294. Ruffell B, Chang-Strachan D, Chan V, Rosenbusch A, Ho CM, Pryer $\mathrm{N}$, et al. Macrophage IL-10 blocks $\mathrm{CD}^{+} \mathrm{T}$ cell-dependent responses to chemotherapy by suppressing IL-12 expression in intratumoral dendritic cells. Cancer Cell (2014) 26:623-37. doi: 10.1016/j.ccell.2014.0 9.006

Conflict of Interest Statement: The authors declare that the research was conducted in the absence of any commercial or financial relationships that could be construed as a potential conflict of interest.

Copyright $\odot 2019$ Dwyer, Knochelmann, Smith, Wyatt, Rangel Rivera, Arhontoulis, Bartee, Li, Rubinstein and Paulos. This is an open-access article distributed under the terms of the Creative Commons Attribution License (CC BY). The use, distribution or reproduction in other forums is permitted, provided the original author $(s)$ and the copyright owner(s) are credited and that the original publication in this journal is cited, in accordance with accepted academic practice. No use, distribution or reproduction is permitted which does not comply with these terms. 